\title{
Abrogation of $\beta$-Catenin Signaling in Oligodendrocyte Precursor Cells Reduces Glial Scarring and Promotes Axon Regeneration after CNS Injury
}

\author{
Justin P. Rodriguez, ${ }^{1,2}$ Michael Coulter, ${ }^{2}$ Jill Miotke, ${ }^{3}$ Ronald L. Meyer, ${ }^{3}{ }^{\circledR}$ Ken-Ichi Takemaru, ${ }^{4}$ and Joel M. Levine ${ }^{2}$ \\ ${ }^{1}$ Program in Neuroscience and ${ }^{2}$ Department of Neurobiology and Behavior, Stony Brook University, Stony Brook, New York 11794, ${ }^{3}$ Department of \\ Developmental and Cell Biology, University of California, Irvine, California 92697, and ${ }^{4}$ Department of Pharmacology, Stony Brook University, Stony Brook, \\ New York 11794
}

When the brain or spinal cord is injured, glial cells in the damaged area undergo complex morphological and physiological changes resulting in the formation of the glial scar. This scar contains reactive astrocytes, activated microglia, macrophages and other myeloid cells, meningeal cells, proliferating oligodendrocyte precursor cells (OPCs), and a dense extracellular matrix. Whether the scar is beneficial or detrimental to recovery remains controversial. In the acute phase of recovery, scar-forming astrocytes limit the invasion of leukocytes and macrophages, but in the subacute and chronic phases of injury the glial scar is a physical and biochemical barrier to axonal regrowth. The signals that initiate the formation of the glial scar are unknown. Both canonical and noncanonical signaling Wnts are increased after spinal cord injury (SCI). Because Wnts are important regulators of OPC and oligodendrocyte development, we examined the role of canonical Wnt signaling in the glial reactions to CNS injury. In adult female mice carrying an OPC-specific conditionally deleted $\beta$-catenin gene, there is reduced proliferation of OPCs after SCI, reduced accumulation of activated microglia/macrophages, and reduced astrocyte hypertrophy. Using an infraorbital optic nerve crush injury, we show that reducing $\beta$-catenin-dependent signaling in OPCs creates an environment that is permissive to axonal regeneration. Viral-induced expression of Wnt3a in the normal adult mouse spinal cord induces an injury-like response in glia. Thus canonical Wnt signaling is both necessary and sufficient to induce injury responses among glial cells. These data suggest that targeting Wnt expression after SCI may have therapeutic potential in promoting axon regeneration.

Key words: glia; inflammation; repair; Wnt

\section{Introduction}

When the brain or spinal cord is injured, glial cells at the injury site undergo biochemical and morphological changes that result in the formation of a glial scar (Silver and Miller, 2004). One common characteristic of the glial reactions to different types of injury is the activation of a population of unusual glial cells known alternatively as oligodendrocyte precursor cells (OPCs), polydendrocytes (Nishiyama et al., 2009), or NG2 cells (Levine et al., 2001). This activation includes a shortening of the cell cycle (Simon et al., 2011), the withdrawal of long multibranched processes into shorter thick processes, enlargement of the cell body, and an accumulation of the cells into a dense cellular plaque

Received Nov. 22, 2013; revised May 25, 2014; accepted June 18, 2014.

Author contributions: J.P.R., R.L.M., and J.M.L. designed research; J.P.R., M.C., and J.M. performed research; K.-I.T. contributed unpublished reagents/analytic tools; J.P.R. analyzed data; R.L.M., K.-I.T., and J.M.L. wrote the paper.

This work was supported by an NMSS Collaborative Research Center Grant to J.M.L., National Institutes of Health (NIH) Grant HL107493 to K.-I.T., and an NIH predoctoral fellowship to J.P.R.

The authors declare no competing financial interests.

Correspondence should be addressed to Joel Levine, Department of Neurobiology and Behavior, Stony Brook University, Stony Brook, NY 11794-5230. E-mail: Joel.Levine@stonybrook.edu.

DOI:10.1523/JNEUROSCI.4915-13.2014

Copyright $\odot 2014$ the authors $\quad 0270-6474 / 14 / 3410285-13 \$ 15.00 / 0$ surrounding the injury site. OPCs function as precursors cells to oligodendrocytes and participate in the formation of new myelin throughout the life of the animal (Young et al., 2013). Since they are postsynaptic targets for glutaminergic and GABAergic input in the hippocampus and cerebellum (Paukert and Bergles, 2006), they likely carry out other functions that have yet to be fully characterized. Their functions during injury and wound healing are also not well understood, although they secrete or shed growth-inhibitory chondroitin sulfate proteoglycans that are a factor in the inhibition of axonal regeneration (Tan et al., 2006; Donnelly et al., 2012; Petrosyan et al., 2013).

The injury-induced changes in OPCs occur precisely at the injury site suggesting that some feature of the local environment may trigger this activation. What these features are remains unknown. Multiple members of the Wnt family of developmental morphogens and their receptors are rapidly increased at sites of brain and spinal cord injury (SCI; Liu et al., 2008a; Miyashita et al., 2009; Fernández-Martos et al., 2011; Gonzalez et al., 2012). While mostly known for their role as developmental regulators, Wnts have multiple functions in the adult brain (Inestrosa and Arenas, 2010).

Here we asked whether canonical Wnt signaling plays a role in the activation of OPCs after contusive SCI. Canonical Wnt sig- 

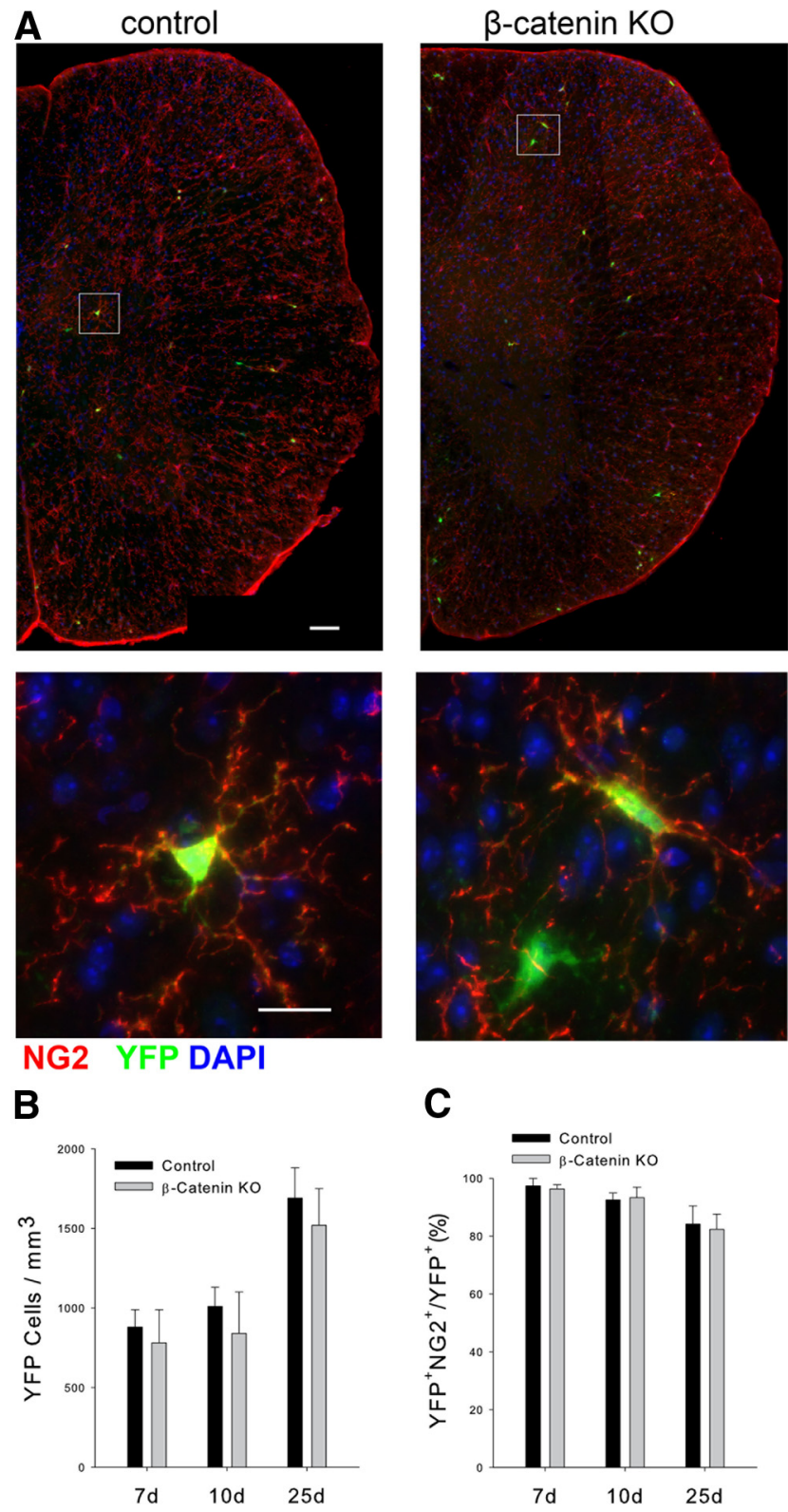

Figure 1. Characterization of the $\beta$-catenin $\mathrm{K} 0$ and control animals. $\boldsymbol{A}$, The appearance of YFP + cells in control and $\beta$-catenin $\mathrm{KO}$ spinal cord $10 \mathrm{~d}$ after initiating tamoxifen treatment. Scale bar, $50 \mu \mathrm{m}$. Bottom shows individual YFP +, NG2 + OPCs from both genotypes. Scale bar, $10 \mu \mathrm{m} . \boldsymbol{B}$, Quantitation of the density of YFP + cells at the indicated times after initiating tamoxifen treatment. $\boldsymbol{C}$, The percentage of YFP + cells colabeled with NG2. There is no statistical difference in the density of OPCs between the two genotypes; $n=3$ for all time points and groups.

naling is dependent on cytoplasmic $\beta$-catenin. In the absence of Wnt ligands, $\beta$-catenin is destroyed by a complex of axin, adenomatous polyposis coli, and active glycogen synthase kinase $3 \beta$ (GSK3 $\beta$; Kimelman and $\mathrm{Xu}, 2006$ ). After binding of Wnts to a frizzled-LRP receptor complex, GSK3 $\beta$ activity is inhibited allowing $\beta$-catenin to accumulate in the cytoplasm and subsequently translocate to the nucleus where it binds to TCF/LEF transcription factors and activates gene transcription (Cadigan and Liu, 2006). Here, we conditionally knocked out $\beta$-catenin specifically in OPCs before injuring the thoracic spinal cord. The results indicate that canonical Wnt signaling is required for the injury-induced activation of OPCs. Surprisingly, attenuation of the OPC response also attenuated microglial activation and astrocyte hypertrophy. Furthermore, knocking out $\beta$-catenin al-

\section{A uninjured control} control
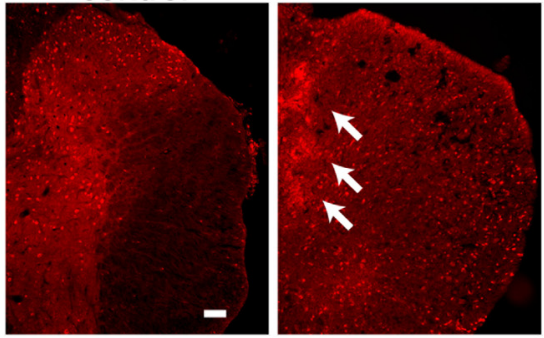
$\beta$-catenin $\mathrm{KO}$

\section{Axin2}

B
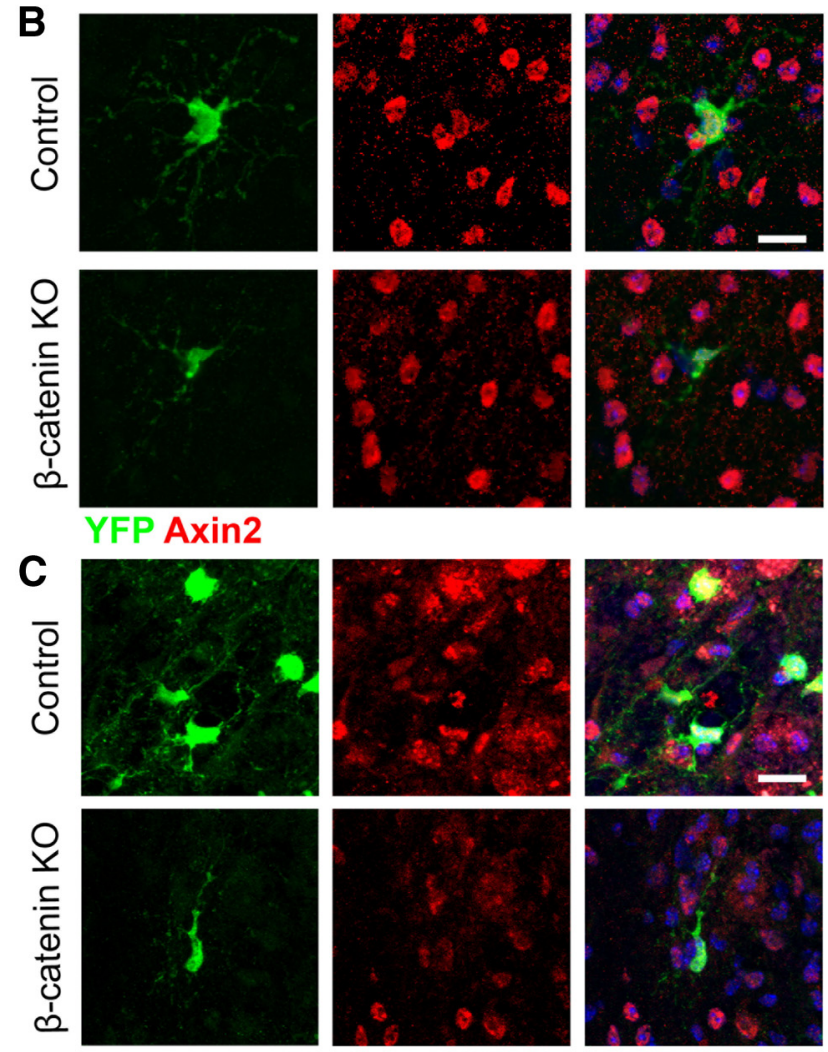

D
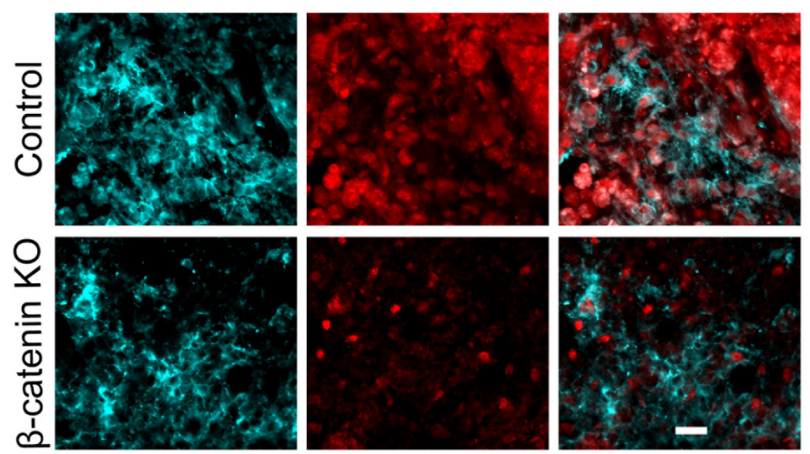

NG2 Axin2

Figure 2. Axin2 immunoreactivity in control and $\mathrm{KO}$ mice. $A$, Anti-axin2 staining of wildtype uninjured thoracic spinal cord, injured control, and injured K0 spinal cord at $5 \mathrm{dpl}$. Scale bar, $50 \mu \mathrm{m} . \boldsymbol{B}$, Axin2 immunoreactivity in uninjured control and KO YFP-positive OPCs. Axin2 immunoreactivity is reduced in OPCs in the $\beta$-catenin KO mice. Scale bar, $10 \mu \mathrm{m}$. C, Axin2 immunoreactivity in YFP + cells at $5 \mathrm{dpl}$ in injured control and K0 animals. Scale bar, $10 \mu \mathrm{m}$. D, Anti-NG2 and anti-axin2 staining of $5 \mathrm{dpl}$ injured spinal cord in control and KO mice. Scale bar, $15 \mu \mathrm{m}$. Knocking out $\beta$-catenin in OPCs reduces axin 2 expression throughout the spinal cord and in both the YFP + and NG2 + cell populations. 
A
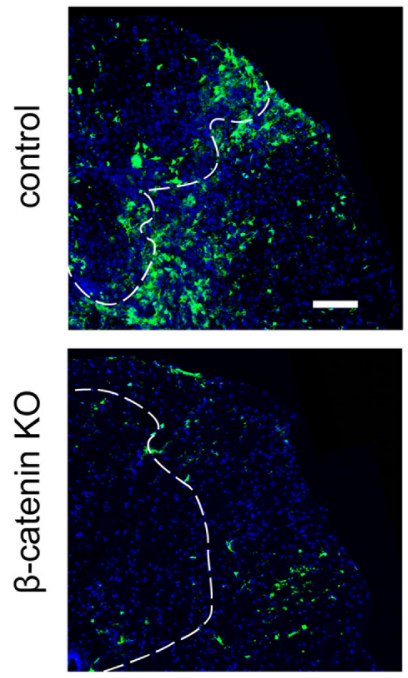

YFP DAPI

B

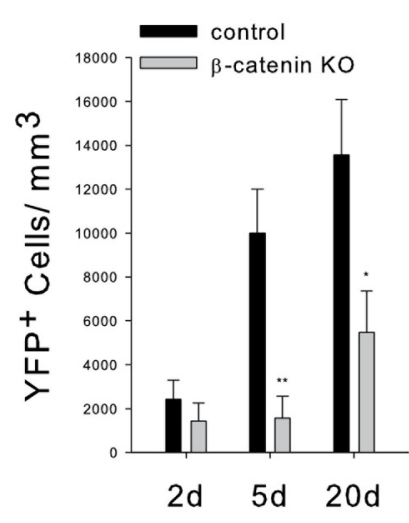

C
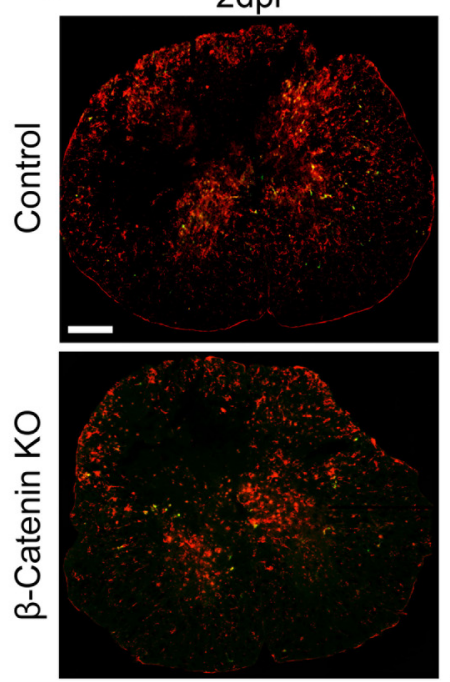

NG2 YFP

D
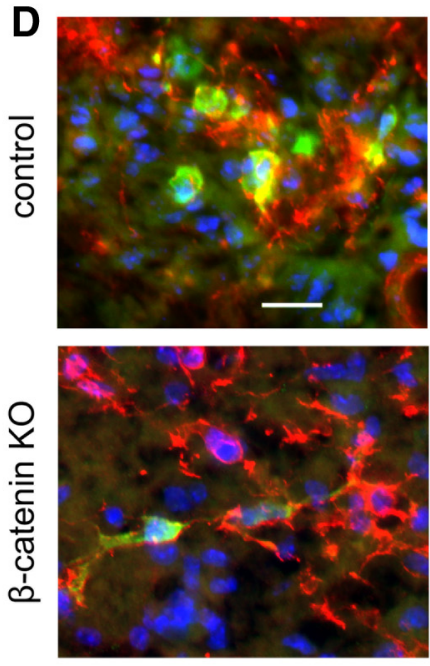

NG2 YFP DAPI
5 dpi
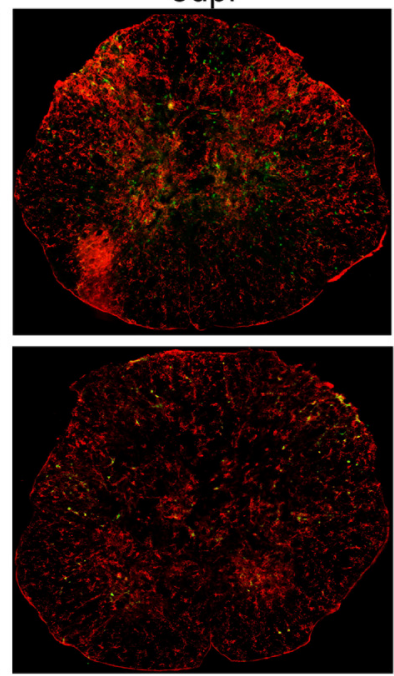

E
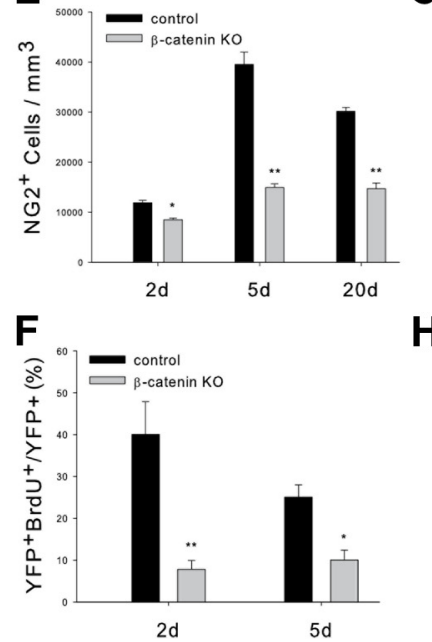

20dpi
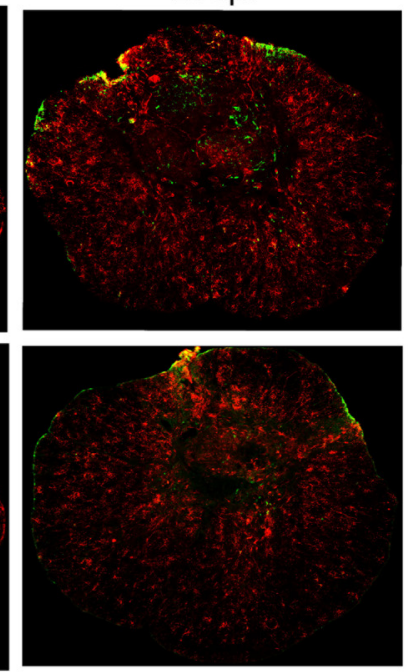

G

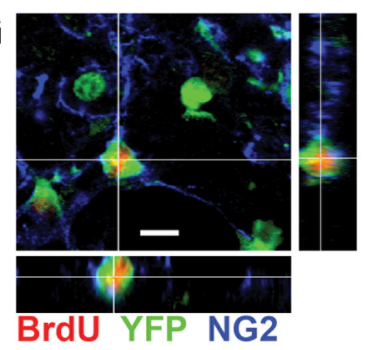

H

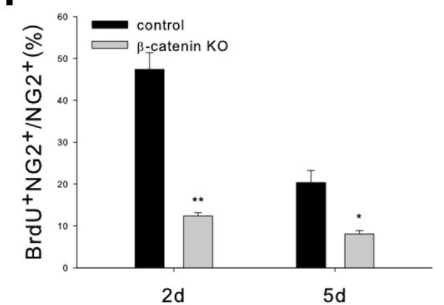

Figure 3. OPC proliferation and accumulation after injury is reduced in the $\beta$-catenin $\mathrm{KO}$ mice. $A$, Appearance of YFP-positive cells surrounding the lesion site at $5 \mathrm{dpi}$. The dotted line outlines the contusion site. $\boldsymbol{B}$, Quantitation of the density of YFP + cells at the indicated postinjury times, $n=4$. C, The appearance of YFP,$+ N G 2+O P C$ at the indicated postinjury times. In control animals, $\mathrm{OPCs}$ accumulate around the lesion site, retract their processes, and have increased immunoreactivity for NG2. In the $K 0$ animals, OPCs retain their ramified appearance at all postinjury survival times. $D$, High-power views of YFP,$+ N G 2+$ cells at $5 \mathrm{dpl}$. In control animals, the cells have swollen cell bodies and short processes whereas KO NG2+, YFP + retain their long multibranched processes. $E$, Quantitation of the density of NG2 + OPCs at the indicated postinjury times, $n=4$. F, Quantitation of BrdU incorporation into YFP + cells at the indicated postinjury times, $n=4$. G, An example of a BrdU +, YFP +, and NG2 + cell in control animal 5 dpi. $\boldsymbol{H}$, Quantitation of BrdU incorporation into NG2 + cells at the indicated postinjury times, $n=4 . \boldsymbol{B}, \boldsymbol{E}, \boldsymbol{F}$, and $\boldsymbol{H},{ }^{*} p<0.02$, ${ }^{* *} p<0.005$. Scale bars: $A, C, 50 \mu \mathrm{m} ; \boldsymbol{D}, 15 \mu \mathrm{m} ; \mathbf{G}, 10 \mu \mathrm{m}$.

lows retinal ganglion cell axons to regenerate beyond the injury zone in the crushed optic nerve. Thus, OPC activation is a critical component of glial scar formation and requires canonical Wnt signaling.

\section{Materials and Methods \\ Animals}

B6.129-Ctnnb1 ${ }^{\text {tm2Kem } / K n w J ~(~} \beta$-catenin ${ }^{\mathrm{f} / \mathrm{f}}$ ) (Brault et al., 2001) and

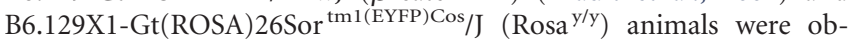
tained from The Jackson Laboratory. PDGFr $\alpha^{\text {creERT2/+ }}$ (Rivers et al., 2008) animals were obtained from Dr. B. Popko (University of Chicago, Chicago, IL). All strains were back-crossed onto a C57BL/6J background for $>6$ generations. Three breeding stocks were created: PDGFr $\alpha^{\text {creERT2/+ }}$ $\operatorname{Rosa}^{\mathrm{y} / \mathrm{y}}$, PDGFr $\alpha^{\text {creERT2/+ }} \operatorname{Rosa}^{\mathrm{y} / \mathrm{y}} \beta$-catenin ${ }^{\mathrm{f} / \mathrm{f}}$, and Rosa ${ }^{\mathrm{y} / \mathrm{y}} \beta$-catenin ${ }^{\mathrm{f} / \mathrm{f}}$. The PDGFr $\alpha^{\text {creERT2/+ }}$ Rosa $^{\mathrm{y} / \mathrm{y}}$ and $\operatorname{Rosa}^{\mathrm{y} / \mathrm{y}} \beta$-catenin ${ }^{\mathrm{f} / \mathrm{f}}$ stocks were created by crossing PDGFr $\alpha^{\text {creERT2 }}$ and $\beta$-catenin ${ }^{\mathrm{f} / \mathrm{f}}$ animals on Rosa ${ }^{\mathrm{y} / \mathrm{y}}$ twice.
PDGFr $\alpha^{\text {creERT2/+ }}$ Rosa $^{\mathrm{y} / \mathrm{y}} \beta$-catenin ${ }^{\mathrm{f} / \mathrm{f}}$ animals were generated by breeding PDGFr $\alpha^{\text {creERT2/+ }}$ animals twice on $\beta$-catenin ${ }^{\mathrm{f} / \mathrm{f}}$ animals then crossing the PDGFr $\alpha^{\text {creERT2/+ }^{2} \beta \text {-catenin }}{ }^{\mathrm{f} / \mathrm{f}}$ progeny with $\operatorname{Rosa}^{\mathrm{y} / \mathrm{y}} \beta$-catenin ${ }^{\mathrm{f} / \mathrm{f}}$ to introduce the Rosa reporter. Viral overexpression experiments were conducted in C57BL/6J animals.

\section{Tamoxifen induction}

Tamoxifen was dissolved in ethanol at a concentration of $1 \mathrm{~g} / \mathrm{ml}$ then dissolved in vegetable oil (19:1) with 5 min of sonication to a final concentration of $50 \mathrm{mg} / \mathrm{ml}$ and frozen. Frozen stocks of tamoxifen were warmed to $37^{\circ} \mathrm{C}$ and sonicated for $1 \mathrm{~min}$ before use. Tamoxifen was administered via oral gavage at a dose of $600 \mathrm{mg} / \mathrm{kg} 1 \times$ daily for $3 \mathrm{~d}$.

\section{Surgical methods}

SCI. Female mice of 6-8 weeks of age were used throughout these experiments. Animals were deeply anesthetized using isoflurane. The spinal column was exposed from T7-T9 and a laminectomy was performed at 
A
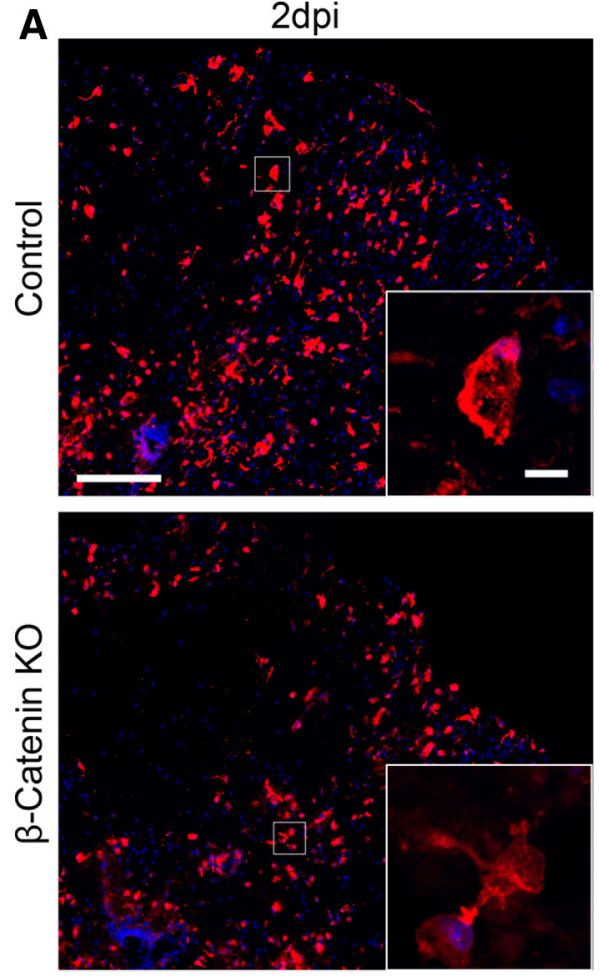

Iba1 DAPI
$5 \mathrm{dpi}$
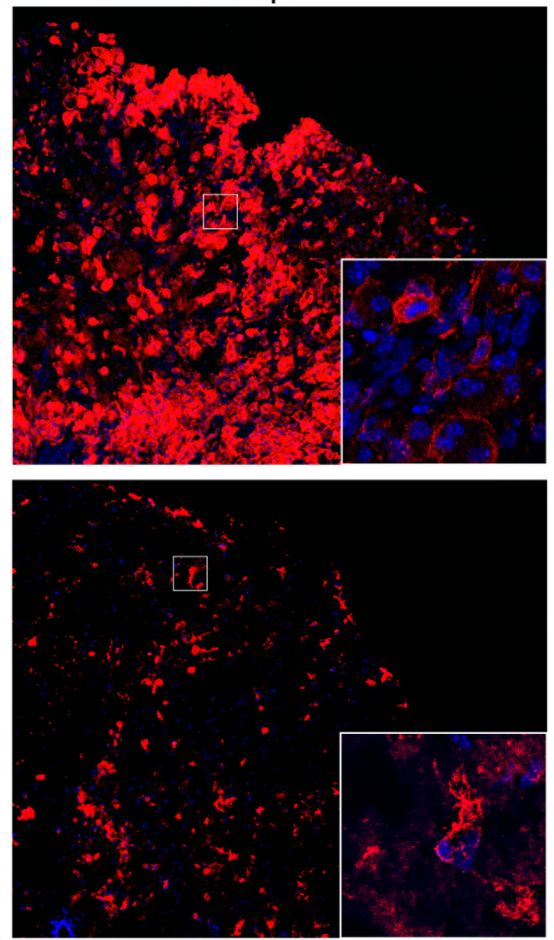

B

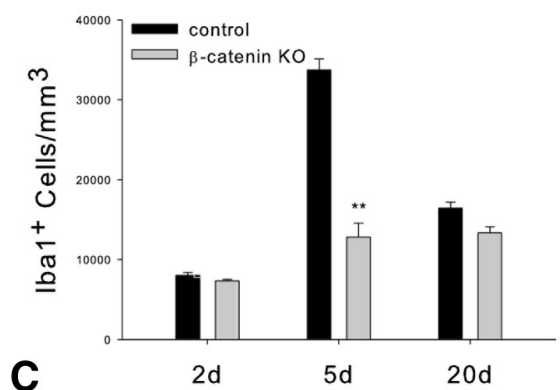

C

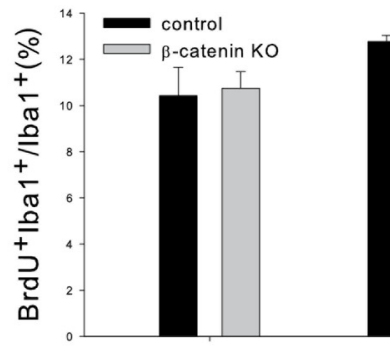

$2 d$

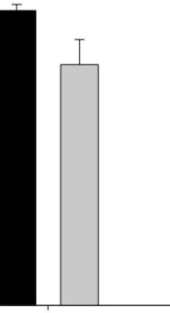

$5 d$

Figure 4. Injury-induced reactions of microglia are reduced in the $\beta$-catenin $\mathrm{K} 0$ animals. $A$, The appearance of microglia/ macrophages in control and $\mathrm{K} 0$ animals at the indicated postinjury survival times. $\boldsymbol{B}$, Quantitation of the density of Iba $1+$ cells in the injury penumbra at the indicated postinjury survival times; ${ }^{* *} p<0.001 . n=4$. $C$, BrdU incorporation in Iba $1+$ cells at the indicated postinjury times. There is no statistically significant difference in the percentage of lba1+ cells that take up BrdU in the two genotypes. Scale bars: $A, 100 \mu \mathrm{m} ;$ insets, $10 \mu \mathrm{m}$.

T8. The lateral processes at T7 and T9 were stabilized with immobilized forceps attached to the Infinite Horizon Impactor (Precision Systems and Instrumentation) and a contusion of 45 kdyn was delivered. Hemostasis was obtained with Gelfoam, and the deep muscles, superficial muscles, and skin were sutured in layers. During recovery, animals were given $50 \mathrm{mg} / \mathrm{kg}$ buprenorphine $2 \times$ daily for $4 \mathrm{~d}$.

Viral injections. After a laminectomy and stabilization of the cord as described above, a durotomy was performed at T8. AAV virus diluted in PBS to $1 \times 10^{11}$ viral genomes/ml was slowly injected into the border of the dorsal columns and dorsal horn using a sharpened glass micropipette (4-6 $\mu \mathrm{m}$ opening) and a Picospritzer (General Valve) programmed to deliver $15-25 \mathrm{~ms}$ pulses at $1 \mathrm{~Hz}$ and 25 psi over $10 \mathrm{~min}$ such that a total of $0.5 \mu \mathrm{l}$ of virus was injected. The injection was aimed by centering the needle over the spinal cord then moving laterally $300 \mu \mathrm{m}$. The needle was inserted $500 \mu \mathrm{m}$ into the spinal cord then brought back to a final depth of $300 \mu \mathrm{m}$.

Optic nerve crush. Animals were anesthetized locally with $0.5 \%$ proparacaine hydrochloride ophthalmic solution and generally with isoflurane. An optic nerve crush was performed as described previously (Meyer and Miotke, 1990; Meyer et al., 1994). In brief, the lateral conjunctival membrane was cut and lateral muscles bluntly dissected to expose the optic nerve. The nerve was then crushed with \#5 biologie forceps (Dumont) for $5 \mathrm{~s}$. No compounds were administered to either promote retinal ganglion cell (RGC) survival or to upregulate their intrinsic growth state (Leon et al., 2000; Kurimoto et al., 2010). At $19 \mathrm{~d}$ post crush, $2 \mu \mathrm{g}$ of Alexa Fluor 594-conjugated cholera toxin subunit B (CTB; Invitrogen) was injected into the vitreous space of the inured eye. The animals were killed $21 \mathrm{~d}$ post crush when the maximum number of axons was detected distal to the injury site in previous studies (Leon et al., 2000).

All procedures using animals were approved by the Institutional Animal Use Committee.

$A A V$

Mouse Wnt3a and Wnt5a-expressing AAV2 virus was prepared as follows. The ORF of Wnt3a and Wnt5a was cloned into the AAV-IRES-
hrGFP vector (Stratagene) and virus was created according to the Stratagene helper-free system protocol. In brief, virus plasmid, pHelper, and pAAV-RC were transfected into AAV-293 cells. The cells were lysed by freeze thawing and the virus was concentrated via the ViraBind system (Cell Biolabs). GFP virus was a gift from Dr. W. Bowers (University of Rochester, Rochester NY). Viral genome copy numbers were calculated according to their optical density at 260 and $280 \mathrm{~nm}$ (Sommer et al., 2003).

\section{Tissue preparation}

Animals were deeply anesthetized and transcardially perfused with $50 \mathrm{ml}$ of room temperature PBS followed by $50 \mathrm{ml}$ of ice-cold $4 \%$ formaldehyde in $100 \mathrm{~mm} \mathrm{~PB}, \mathrm{pH}$ 7.4. Tissue was dissected from the animals and postfixed in the formaldehyde solution for $4 \mathrm{~h}$ at $4^{\circ} \mathrm{C}$. Optic nerves were equilibrated with PBS for $12 \mathrm{~h}$ before clearing. Spinal cord tissue was prepared for cryostat sectioning by equilibrating the tissue with $30 \%$ sucrose in $100 \mathrm{~mm} \mathrm{~PB}, \mathrm{pH}$ 7.4, for $48 \mathrm{~h}$. Tissue was frozen in Cryo-Gel embedding media (Instrumedics) in dry ice-cooled 2-methylbutane. Coronal sections $20 \mu \mathrm{m}$ thick were prepared using standard cryostat procedures.

\section{Optic nerve clearing}

Optic nerves were organically desiccated and solvent cleared as described previously (Ertürk et al., 2012). Four percent formaldehydefixed optic nerves were incubated in solutions of 50, 80, and $100 \%$ tetrahydrofuran in water for $30 \mathrm{~min}$ each and then placed in $100 \%$ dichloromethane for $20 \mathrm{~min}$. The nerves were placed in a 1:2 solution of benzyl alcohol and benzyl benzoate (BAAB) for 3 min and mounted onto uncoated slides in BAAB solution using a strip of Parafilm as a spacer.

\section{Immunofluorescence staining}

Immunofluorescence staining of tissue sections and cell cultures was performed as described previously (Levine et al., 1993). Primary antibodies are listed at the end of the Materials and Methods section. 

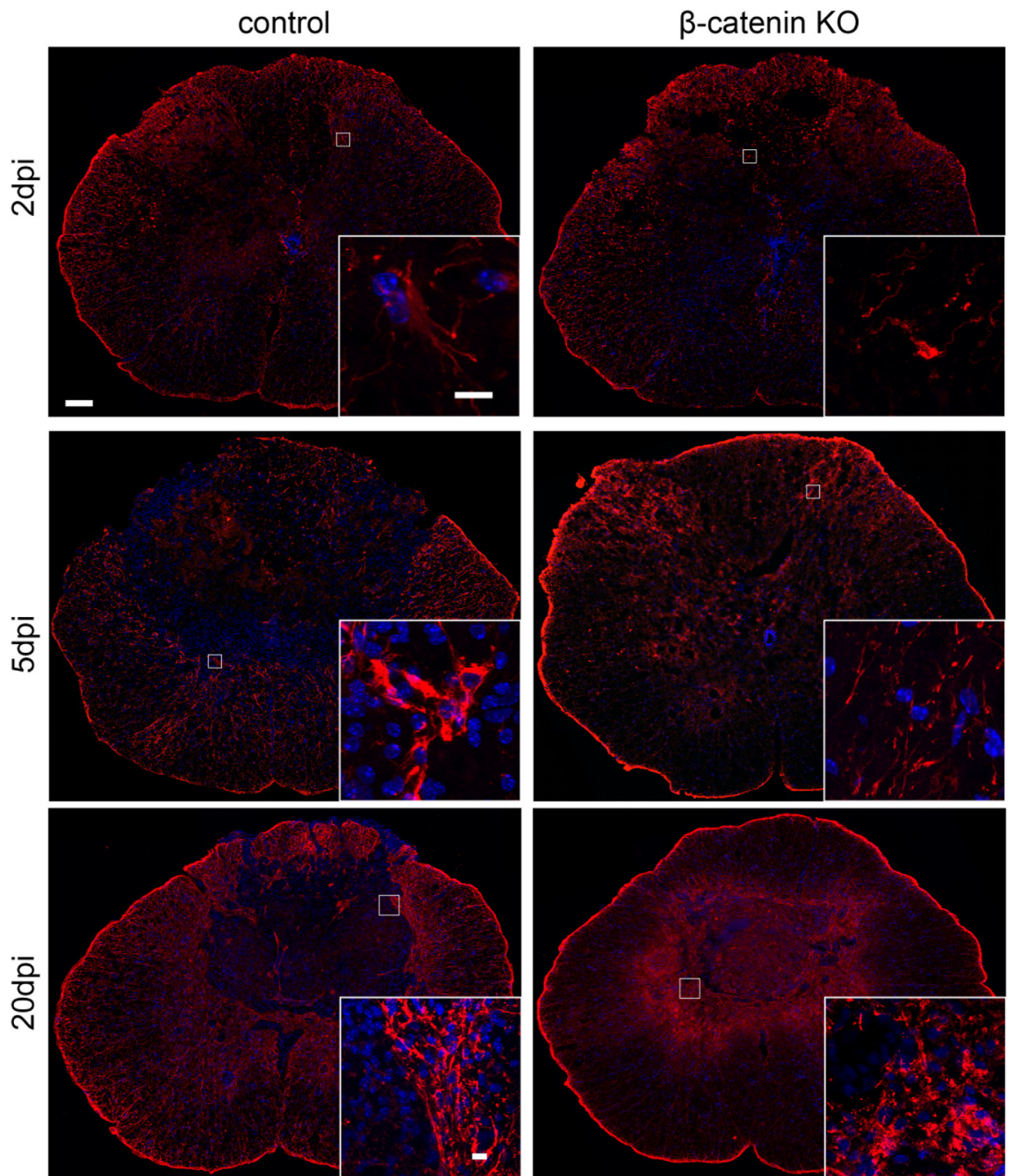

GFAP DAPI

Figure 5. Astrocyte hypertrophy is reduced in the K0 animals. GFAP-immunoreactivity at the indicated postinjury survival times in control and $\beta$-catenin $\mathrm{KO}$ animals. Insets show higher magnification views of the boxed areas. Astrocytes are hypertrophic at 5 dpi in the control animals but appear unchanged in the $K 0$ animals. At 20 dpi, astrocytes form a compact border around at the injury site; $\mathrm{K} 0$ astrocytes are irregular in appearance and do not form a compact border. Scale bars: $A, 50 \mu \mathrm{m}$; insets, $10 \mu \mathrm{m}$.

\section{control}

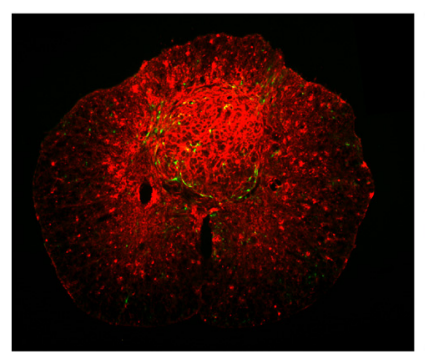

\section{CS56}

Figure 6. CSPG immunoreactivity is reduced in the $\mathrm{KO}$ spinal cords. Monoclonal antibody CS-56 stain of control and KO spinal cords at $20 \mathrm{dpl}$. Scale bar, $100 \mu \mathrm{m}$.

Secondary antibodies were all raised in donkey. Alexa Fluor(AF)-488 anti-chicken, AF-647 anti-rabbit, and AF-647 anti-rat were obtained from Jackson ImmunoResearch, and AF-594 anti-rabbit and AF-594 anti-rat were obtained from Invitrogen.

\section{BrdU labeling}

Animals were administered two intraperitoneal injections $(10 \mathrm{mg} / \mathrm{kg})$ of BrdU in normal saline 4 and $2 \mathrm{~h}$ before being killed and perfused with $4 \%$ PFA. Staining was performed using antigen retrieval as described previously (Morgan et al., 1994, 1997; Tang et al., 2007).

\section{In vitro methods}

Dissociated cultures of OPCs were prepared as described previously (McCarthy and de Vellis, 1980; Yang et al., 2005). OPCs were isolated from $\mathrm{P} 0-\mathrm{P} 2$ rats and expanded in a mixed glial culture in DMEM $+10 \%$ FBS. The cultures were shaken to suspend OPCs, and the cells were subjected to two sessions of differential adhesion for $30 \mathrm{~min}$ to enrich for OPCs. OPCs were plated on PLL-coated glass coverslips in DMEM $+10 \%$ FBS and permitted to adhere for $4 \mathrm{~h}$ before being cultured in defined media. Basic oligodendrocyte differentiation media was DMEM, N2 supplement (Gemini BioProducts), $0.5 \%$ FBS, $100 \mathrm{U} / \mathrm{ml}$ penicillin, 100 $\mu \mathrm{g} / \mathrm{ml}$ streptomycin (Life Technologies), 40 $\mathrm{ng} / \mathrm{ml}$ thyroxine (T4), and $30 \mathrm{ng} / \mathrm{ml}$ triiodothyronine (T3; Sigma). In different experiments, this media was supplemented with either $10 \mathrm{ng} / \mathrm{ml}$ PDGF-AA (PeproTech), Wnt conditioned media as described below, or pure Wnt3a (Millipore). L-cells stably transfected to express Wnt3a and Wnt5a and control L-cells were obtained from ATTC. Conditioned media was prepared by growing the cells to $90 \%$ confluence and incubating the cells in DMEM containing $0.5 \%$ FBS for $3 \mathrm{~d}$. The media was collected, centrifuged to remove cellular debris, filtered, and stored at $4^{\circ} \mathrm{C}$. A human $\mathrm{Fc}$ mouse Frizzled-5 cysteine-rich domain fusion protein (Fzl5-CRD-IgG) was purified using protein A chromatography from conditioned media collected from stably transfected 293T cells.

\section{Analytical methods}

Imaging. Confocal imaging was performed on an Olympus FluoView confocal microscope. Wide field images were obtained on a Zeiss Axioskop II with AxioVision (Zeiss) software and were stitched together in Photoshop (Adobe). Stereology was performed using Stereo Investigator and Neurolucida (MicroBrightField) attached to a Zeiss Axioskop II.

$S C I$. We counted cells within the penumbra region of the lesions using the optical fractionator probe of Stereo Investigator (MicroBrightField). We define the penumbra as a region $150 \mu \mathrm{m}$ wide surrounding the lesion core. The lesion core was identified by staining coronal sections of injured spinal cord with anti-GFAP antibodies. GFAP immunoreactivity is lost in the lesion core and upregulated along the borders of the core.

Due to section shrinkage in the $z$-axis, the average mounting thickness was $16 \mu \mathrm{m}$. We used guard intervals at the top and bottom of each section equal to $10 \%(\sim 1.6 \mu \mathrm{m})$ of the mounted thickness to exclude regions of the tissue disrupted by sectioning. The population estimates were performed using a counting frame of $150 \times 150 \mu \mathrm{m}$ and a sampling grid of $300 \times 300 \mu \mathrm{m}$, effectively sampling $25 \%$ of each cord at nonbiased, systematically arranged, and randomly positioned intervals. We counted cells in five sections spaced $200 \mu \mathrm{m}$ apart and centered on the injury epicenter (defined by the section having the largest injury area). All biological replicates had a coefficient of error as calculated by the Gundersen method of $\leq 10 \%$ for each marker (Gundersen, 1986; Gundersen et al., 1999). The cell population densities in each region of interest between PDGFr $\alpha^{\text {CreERT2/+ }}, \beta$-catenin ${ }^{\text {f/f }}$, Rosa26 ${ }^{\text {YFP/YFP, }}$, 
A

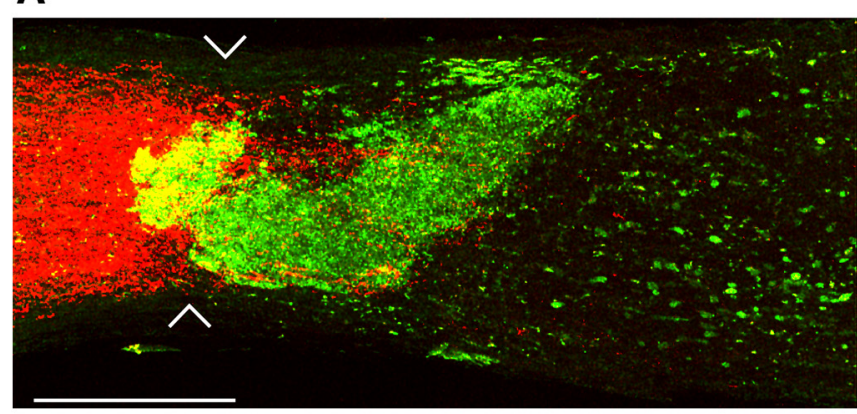

B

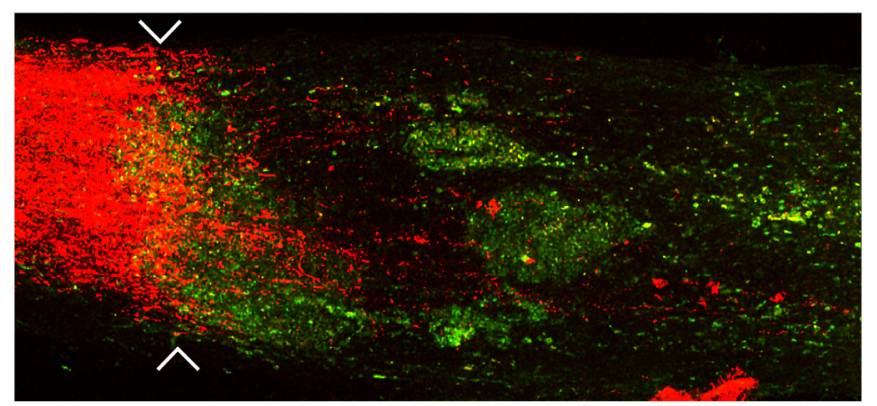

CTB YFP

C

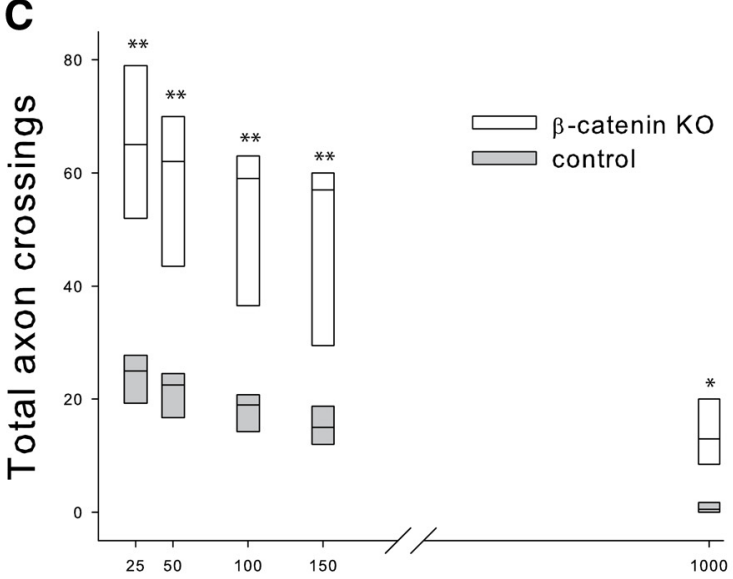

$\mu \mathrm{m}$ from lesion edge
D

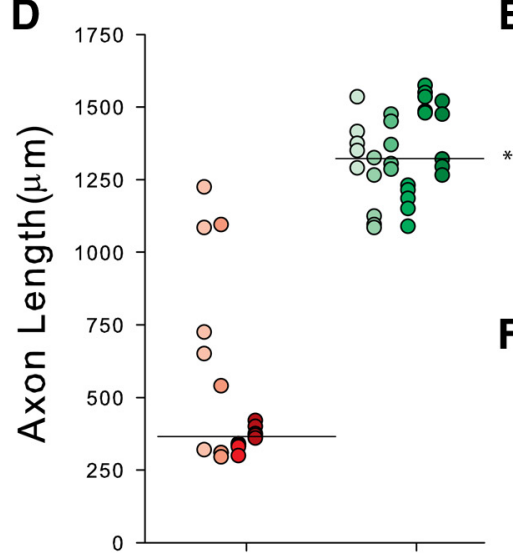

Control Knockout
E

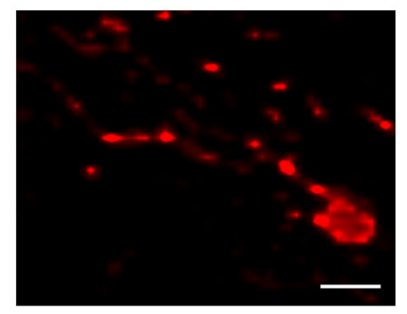

$\mathbf{F}$

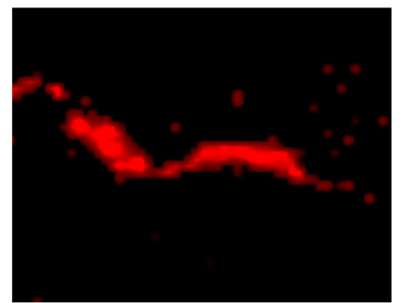

Figure 7. Retinal ganglion cell (RGC) axon regeneration in control and KO animals. $A, B$, Whole-mount preparations of optic nerves 3 weeks after an infraorbital crush. CTB-labeled RGC axons are red. The chevrons indicate the crush site. YFP + cells are abundant in control animals and form a glial scar that is greatly reduced in the K0 animals. CTB-labeled axonal profiles extend past the crush site in the $\mathrm{KO}$ animals. Scale bar, $50 \mu \mathrm{m}$. C, Mean axon number at the indicated distances from the proximal edge of the injury. Control, $n=4 ; \beta$-catenin KO, $n=6$. D, The lengths of the five longest axons in each of the control and $\mathrm{KO}$ animals represented in shades of red and green, respectively. Horizontal line indicates the median for the longest axons in control and $\mathrm{K} 0$ animals. $\boldsymbol{E}$, Confocal image of a dystrophic growth cone from a control animal. $\boldsymbol{F}$, A labeled growth cone in a K0 animal. Note the elongated form and the thin filopodium; ${ }^{* *} p<0.001,{ }^{*} p<0.05$. Scale bar $\boldsymbol{E}$ and $\boldsymbol{F}$, $10 \mu \mathrm{m}$.

and control PDGFr $\alpha^{\text {CreERT2/+ }}$, Rosa26 ${ }^{\text {YFP/YFP }}$ mice at each time point were compared using Student's $t$ test with significance defined as $p \leq$ 0.05 .

Optic nerve. The crush site was identified by YPF expression. Confocal stacks extending through the optic nerve were obtained at the crush site and $1000 \mu \mathrm{m}$ distal to the crush. We counted the total number of axons that crossed planes drawn perpendicular to the nerve at 25, 50,150, and $1000 \mu \mathrm{m}$ from the crush site. The five longest axons were identified by bright-field epifluorescent microscopy and the distance from the edge of the crush was calculated in AxioVision (Zeiss).

Viral injections. Due to the small area of involvement in the viral overexpression model, subsampling within sections was not performed for BrdU double-labeled cells. Five sections spaced $200 \mu \mathrm{m}$ apart were selected surrounding the injection site. An area of interest surrounding all $\mathrm{GFP}+$ cells was drawn to inscribe the extent of viral infection. All doublelabeled Iba1 $+/ \mathrm{BrdU}+$ and NG2 +/BrdU + cells were counted within this area of interest. To determine the density of $\mathrm{NG} 2+$, Iba1 + , and GFAP cells, we counted the total number of cells within a $150 \times 150 \times 16 \mu \mathrm{m}$ area about the centroid of the infected area on three sections centered on the injection. A staining intensity ratio was obtained at the injection site by measuring the average intensity of a $150 \times 150 \mu \mathrm{m}$ area at the centroid of the infected area on a single confocal plane and dividing it by the average intensity of a similar area containing equal portions gray and white matter in the contralateral spinal cord. Two measurements were made per animal and averaged.
Statistical analysis

All datasets were obtained from a biological system and assumed to be part of a normal distribution after passing a Shapiro-Wilk's normality test despite $n<10$. For comparison between control and $\beta$-catenin knock-out $(\mathrm{KO})$ population analysis at 2,5 , and 20 days post injury (dpi), we performed a Student's $t$ test for each time point. To compare multiple groups in the viral overexpression data and in vitro proliferation data, we performed an ANOVA with a post hoc Tukey test. For comparison of axon outgrowth within the optic nerve, we performed a two-way ANOVA with a post hoc Holm-Sidak multiple-comparison test using genotype and distance from lesion edge as independent variables. We assumed $p<0.05$ to be significant.

\section{Primary antibodies}

Primary antibodies included the following: rat anti-BrdU (Accurate Chemical \& Scientific) 1:1000, rabbit anti-GFP (Invitrogen) 1:1000, chicken anti-GFP (Aves) 1:1000, rabbit anti-GFAP (DAKO) 1:2000, rabbit anti-Ibal (Wako) 1:500, rabbit anti-Axin2 (Abcam) 1:500, rabbit anti-NG2 1:1000, mouse anti-O4 (a gift from R. Bansi, University of Connecticut Health Science Center, Farmington, CT) 1:250, mouse anti$\beta$-catenin (Millipore) 1:250, and mouse anti- $\beta$-actin (Sigma) 1:10,000.

\section{Results}

To investigate the role of canonical Wnt signaling in the glial reactions to SCI, we developed a genetic model using two strains 
A

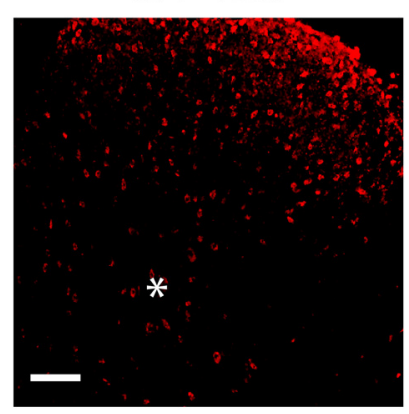

Axin2

\section{B}
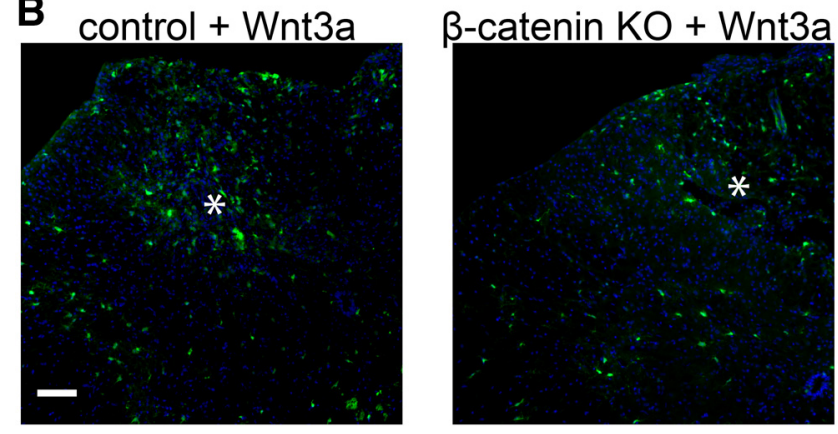

\section{YFP DAPI}

Figure 8. Exogenous Wnt3a activates $\beta$-catenin-dependent canonical signaling. $\boldsymbol{A}$, Axin2 immunoreactivity surrounding virus injection sites (asterisk). $\boldsymbol{B}$, YFP-positive cells after AAVWnt3a virus injection in control or KO mice. Scale bars: $\boldsymbol{A}, \boldsymbol{B}, 50 \mu \mathrm{m}$.

of transgenic mice: PDGFr $\alpha^{\text {CreERT2/+}}, \beta$-catenin ${ }^{\mathrm{f} / \mathrm{f}}$, Rosa26 ${ }^{\text {YFP/YFP }}$ and control PDGFr $\alpha^{\text {CreERT2/+, Rosa26 }}{ }^{\text {YFP/YFP mice. Tamoxifen }}$ treatment of mice carrying the PDGFr $\alpha^{\text {CreERT2/+ }}$, Rosa26 ${ }^{\text {YFP/YFP }}$ mice transgenes results in the expression of YFP almost exclusively in OPCs (Rivers et al., 2008). In the triple transgenic mice ${\text { (PDGFr } \alpha^{\text {CreERT2/+ }}, \beta \text {-catenin }}^{\text {f/f }}$, Rosa $26^{\text {YFP/YFP }}$ ), tamoxifen treatment also results in the deletion of the first five exons of $\beta$-catenin thereby blocking transcription and silencing canonical Wnt signaling (Brault et al., 2001). To validate the cellular specificity and utility of this model, we treated both strains of animals with tamoxifen and counted the number of YFP + cells in the thoracic spinal cord at intervals after treatment (Fig. 1B). After tamoxifen treatment, equal numbers of YFP + cells were present throughout the spinal cord of both strains and the number of YFP + cells approximately doubled between 7 and $25 \mathrm{~d}$ post treatment. There were no significant differences in the appearance of the YFP + cells between the $\beta$-catenin $\mathrm{KO}$ and control animals (Fig. $1 A$ ). At $7 \mathrm{~d}$ post-tamoxifen treatment, $>95 \%$ of the $\mathrm{YFP}+$ cells expressed the OPC marker NG2 and this percentage declined slightly over the next $18 \mathrm{~d}$, most likely reflecting the normal differentiation of the $\mathrm{NG} 2+$ cells into oligodendrocytes (Fig. 1C).

To monitor ongoing $\beta$-catenin-dependent Wnt signaling, we immunofluorescently stained tissue sections for axin2, a direct target for the $\beta$-catenin-TCF transcriptional activator complex (Yan et al., 2001; Jho et al., 2002; Lustig et al., 2002). In the uninjured spinal cord, numerous axin $2+$ cells were present throughout the gray matter and scattered axin $2+$ cells were present in the lateral white matter (Fig. 2A, left). YFP+ cells in the uninjured control animals were axin $2+$, whereas YFP + cells in the $\mathrm{KO}$ animals expressed little or no axin2 protein (Fig. $2 B$ ).
Thus, conditional deletion of $\beta$-catenin in adult spinal cord OPCs reduces canonical Wnt signaling but does not alter the normal appearance or short-term development of the cells.

To confirm that canonical Wnt signaling increases after SCI (Liu et al., 2008a; Miyashita et al., 2009; Gonzalez et al., 2012), control and $\mathrm{KO}$ female mice (6-8 weeks of age) were induced with tamoxifen for 3 and $2 \mathrm{~d}$ later, given moderate ( $45 \mathrm{kdyn}$ ) contusion injuries to the dorsal spinal cord at T10. At $5 \mathrm{~d}$ after a moderate contusion injury ( 5 days post lesion, $\mathrm{dpl}$ ), the number of axin $2+$ cells in control animals had increased and the cells were present throughout both the gray and white matter (Fig. 2A, middle). Axin $2+$ cells were particularly dense along the lesion border (Fig. 2A, middle, arrows). Axin $2+$ cells were present at lower densities in the $\beta$-catenin $\mathrm{KO}$ animals (Fig. 2 , right), although they were still elevated compared with noninjured control animals. YFP + cells in the control animals expressed moderate to high levels of axin2, whereas in the $\beta$-catenin $\mathrm{KO}$ animals, axin 2 immunoreactivity was barely detectable in individual YFP+ cells (Fig. 2C). Of note, many cells that did not express YFP were axin 2+ in both the control and $\mathrm{KO}$ animals. To confirm that OPCs were among the cells expressing axin2, we double stained sections from $5 \mathrm{dpl}$ animals with antibodies against axin2 and NG2. As shown in Figure 2D, in the control animals, NG2+ cells in the lesion penumbra were axin2+ whereas NG2-expressing cells in the KO animals did not contain axin2 immunoreactivity. These data confirm that injury induces canonical Wnt signaling in OPCs and other cells and show that $\beta$-catenin is necessary for this signaling in OPCs.

OPCs proliferate after contusive SCI and accumulate in the penumbral region of the injury site (McTigue et al., 2001; Lytle and Wrathall, 2007; Lytle et al., 2009). To determine whether canonical Wnt signaling is required for this accumulation, we counted the number of YFP + cells in the area surrounding the injury site using nonbiased stereology as described previously (see Materials and Methods). As shown in Figure 3, $A$ and $B$, YFP+ cells accumulated in the lesion penumbra in control animals, but this accumulation was much reduced in the $\mathrm{KO}$ animals. In control animals, the number of YFP + cells increased 10 -fold at $5 \mathrm{dpl}\left(1010 \pm 120 / \mathrm{mm}^{3}\right.$ in uninjured cases, $n=4$, $10,017 \pm 2001 / \mathrm{mm}^{3}$ at $5 \mathrm{dpi}, n=4$ ) and continued to increase more slowly thereafter. In contrast, the density of YFP + cells in the $\mathrm{KO}$ animals did not increase significantly between 2 and $5 \mathrm{dpl}$ and was almost threefold less than that of control animals at 20 dpl (Fig. 3B). Consistent with the almost exclusive expression of YFP in NG2+ OPCs, the density of all NG2 + cells in the injury penumbra was also reduced at 2, 5 and $20 \mathrm{dpl}$ in the $\mathrm{KO}$ animals compared with control animals (Fig. $3 C, E$ ). YFP+, NG2+ cells in the control animals underwent a morphological transformation typical of the injury response. At $5 \mathrm{dpl}$, they had shortened processes and enlarged cell bodies (Fig. 3D). In contrast, YFP+, $\mathrm{NG2}+$ cells in the KO animals retained their stellate appearance and their long multibranched processes (Fig. 3D). The reduced density of the NG2 + and YFP + cells in the KO animals arises, at least in part, from a failure of the $\beta$-catenin $\mathrm{KO}$ cells to proliferate as shown by reduced BrdU incorporation at 2 and $5 \mathrm{dpl} \mathrm{com-}$ pared with control YFP+ cells (Fig. $3 F, G$ ). BrdU incorporation into the total $\mathrm{NG} 2+$ cell population was reduced in the $\mathrm{KO}$ animals to an extent similar to that of the YFP+ cells (Fig. $3 H$ ). As the glial scar matured between 5 and $20 \mathrm{dpl}$, the number of YFP+ cells in both genotypes increased and the number of NG2 + cells decreased, most likely reflecting the continuing proliferation and differentiation of YFP + cells into either NG2-oligodendrocytes or Schwann cells (McTigue et al., 2001; Zawadzka et al., 2010). 
Thus, abrogating $\beta$-catenin signaling in OPCs reduces their proliferation and accumulation in the tissue surrounding SCI.

SCI results in astrocyte hypertrophy and microglial proliferation and accumulation (Dahl and Bignami, 1974; Giulian et al., 1989). Whether the initial reactions of OPCs to injury play a role in the subsequent reactions of these glial cell types is unknown. We therefore next asked whether reducing the OPC reaction to SCI alters the injury-induced responses of microglia, macrophages, and astrocytes. Reactive microglia and macrophages were identified using a polyclonal antibody against Ibal that identifies both of these two cell types. As shown in Figure 4, $A$ and $B$, the accumulation of microglia/macrophages around the injury site was reduced in the $\beta$-catenin $\mathrm{KO}$ animals compared with control animals, particularly at $5 \mathrm{dpl}$ when the microglia/macrophage reaction is at its maximum. The insets show that the Iba1 + cells present in the KO animals had ramified processes compared with cells in the control animals, which had the amoeboid appearance typical of activated cells. The accumulation of microglia/ macrophages after SCI arises from both cell migration and local cell division. Surprisingly, there were no differences in the ratio of Iba1 + cells incorporating BrdU (Fig. $4 C$ ) at 2 and $5 \mathrm{dpl}$, suggesting that the reduced cell accumulation in the $\mathrm{KO}$ animals is due to a failure of inflammatory cell mobilization and migration rather than reduced proliferation.

The astrocyte hypertrophy that follows SCI forms a barrier to cell invasion and restores the boundary between CNS and non-CNS tissue (Bush et al., 1999). Astrocytic reactions to contusive injury were also reduced in the $\mathrm{KO}$ animals and overall levels of anti-GFAP immunoreactivity were reduced at $5 \mathrm{dpl}$ in the $\beta$-catenin $\mathrm{KO}$ animals (Fig. 5). This reduction was most apparent at the single cell level, and astrocytes in the KO animals lacked the dense bundles of GFAP-containing intermediate filaments seen in the control cells (Fig. 5, insets). At 20 dpi in control animals, the injury site resolves into a fluid- and cell-filled granuloma encapsulated by the processes of reactive astrocytes (Fig. 5). Although reactive astrocytes were present around the granuloma that forms in the $\mathrm{KO}$ animals, the astrocytic borders of this granuloma were poorly defined compared with the sharp edges seen in the control animals. Thus, when the OPC reaction to injury is suppressed, the reactions of microglia and astrocytes are also muted. This suggests that OPCs, which are among the first cells to react to several different types of CNS injury (Levine et al., 2001), may orchestrate the reactive responses of other glial cells.

Despite these differences in the accumulation of OPCs and microglia after injuries, lesion size did not vary significantly between the control and $\beta$-catenin $\mathrm{KO}$ animals at 2 and $5 \mathrm{dpl}$. There was a slight trend toward smaller lesion sizes at $20 \mathrm{dpl}$ (lesion size was $15 \%$ smaller in the $\mathrm{KO}$ animals), but this did not reach significance $(p=0.06$, Student's $t$ test $)$.
The data presented above show that abrogating canonical Wnt signaling in OPCs after SCI reduces OPC accumulation, inflammation, and reactive astrogliosis. Because OPCs and astrocytes produce large amounts of growth-inhibitory chondroitin sulfate proteoglycans (CSPGs) among other growth-inhibitory molecules, we next asked whether there was a reduced accumulation of CSPGs in the KO animals. As shown in Figure 6, CSPG immunoreactivity was reduced at $20 \mathrm{dpi}$ in the $\mathrm{KO}$ animals compared with the control injured animals. To determine whether glial scar reduction affected the ability of damaged axons to regenerate, we used a minimally invasive infraorbital optic nerve crush model (Fig. 7). After an infraorbital crush, damaged RGC axons sprout but fail to grow into the glial environment of the damaged distal segment unless the growth state of the retinal ganglion neurons is experimentally manipulated (Benowitz and Yin, 2010). We crushed the left optic nerve of control and KO mice and measured axon regeneration 3 weeks later in wholemount preparations of solvent-cleared optic nerves (Ertürk et al., 2012). As shown in Figure 7, $A$ and $B$, YFP + cells accumulate at the crush site in control animals and this accumulation is reduced in the $\mathrm{KO}$ animals. To measure axon regeneration, we counted the total number of axons that crossed planes drawn perpendicular to the nerve at $25,50,150$, and $1000 \mu \mathrm{m}$ from the crush site 
A

GFP

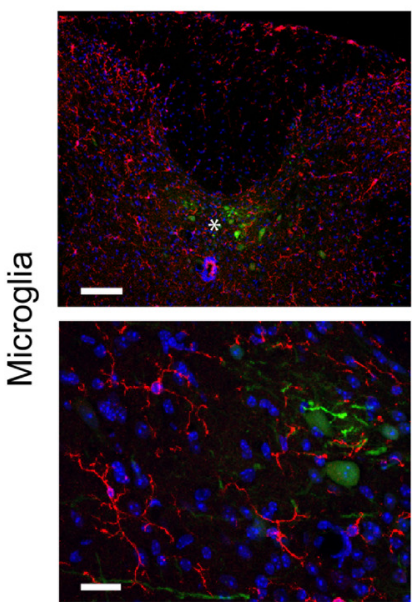

Iba1 GFP DAPI

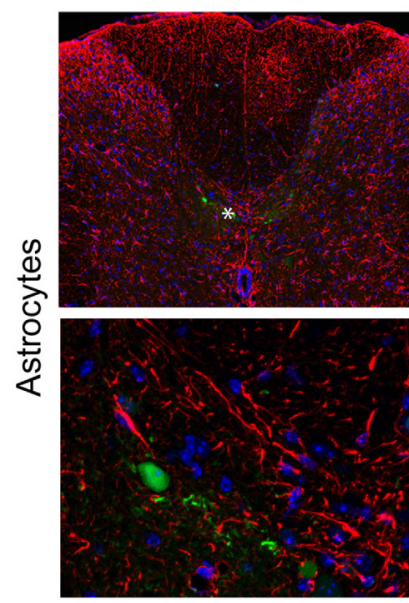

GFAP GFP DAPI

B

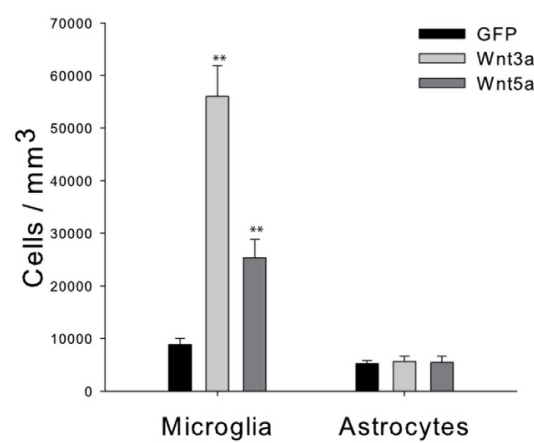

Wnt3a
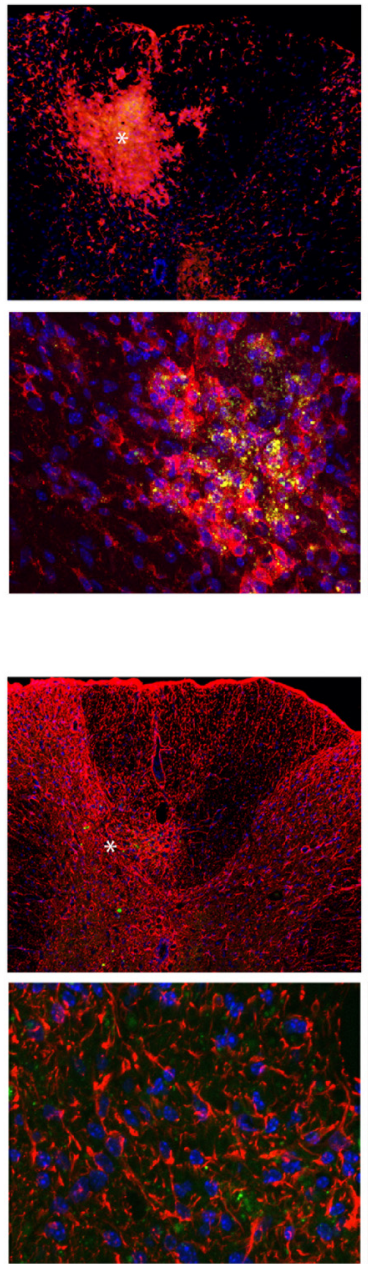

C

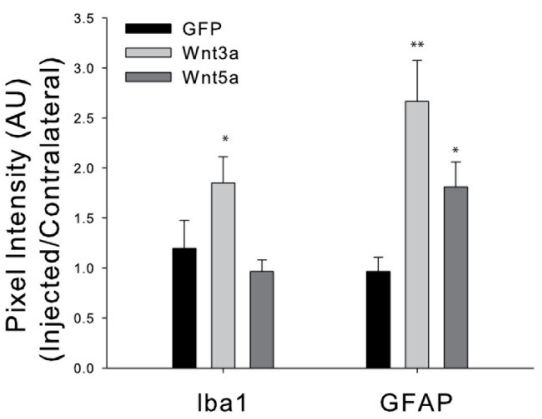

Figure 10. Exogenous Wnts activate microglia/macrophages and induce astrocyte hypertrophy. $\boldsymbol{A}$, The appearance of Iba1positive (red) microglia/macrophages and GFAP-positive astrocytes after AAV virus injection. The second and fourth row show higher power views of the cells. $\boldsymbol{B}$, Quantitation of cell density after virus injection. Microglia but not astrocytes are increased in density after Wnt3a virus injection. C, Pixel intensity for the indicated antigens. Wnt3a induces increases in the expression of Iba1 and GFAP. The effects of Wnt5a are more modest than those of Wnt3a. Wnt3a, $n=8$; Wnt5a, $n=4 ;$ GFP, $n=6 ;{ }^{* *} p=0.001$, ${ }^{*} p=0.01$. Scale bars: $\boldsymbol{A}$, top, $50 \mu \mathrm{m} ; \boldsymbol{A}$, second row, $10 \mu \mathrm{m}$. White asterisk indicates centroid of the injection site.

(Fig. 7C). Approximately three times more axons grew past the proximal edge of the crush site in $\mathrm{KO}$ optic nerves compared with control optic nerves. We also measured the length of the five longest axons in each control and $\mathrm{KO}$ animal (Fig. 7D). The mean length was 3.6-fold longer in the KO mice (1322 \pm $27.3 \mu \mathrm{m}$ in the KO vs $365 \pm 66 \mu \mathrm{m}$ in control animals, mean \pm $\mathrm{SE})$. In the KO animals, many labeled axons had arrowhead- shaped growth cone-like endings (Fig. $7 F$ ) whereas in the control animals, labeled axons had dystrophic end bulbs (Fig. 7E). Thus, reducing glial scarring and associated inflammation creates an environment that is permissive for axon regeneration.

These results suggest that $\beta$-catenindependent canonical Wnt signaling is necessary for the glial reactions to injury. Because $\beta$-catenin also participates in multiple cellular processes (Valenta et al., 2012), we used a gain-of-function approach to determine whether increasing Wnt expression and subsequent $\beta$-catenindependent signaling is sufficient to provoke an injury-like response in glial cells in uninjured animals. We injected AAV viruses expressing GFP alone, Wnt $3 a$ and GFP, or Wnt5a and GFP into the dorsal columns of 6- to 8-week-old female C57BL/6J mice and examined the region surrounding the injection site for reactive-like glial changes $10 \mathrm{~d}$ later. To ensure that the injected viruses were activating canonical Wnt signaling, we performed two control experiments. First, we examined axin 2 reactivity and, as shown in Figure $8 A$, there was a large increase in the expression of axin 2 surrounding the Wnt3a virus injection site. Axin2 was detected in both OPCs and microglia (data not shown). Second, we injected the Wnt3a-expressing virus into control and $\beta$-catenin $\mathrm{KO}$ animals and examined YFP expression. As shown in Figure $8 B$, YFP+ cells were abundant in the control animals but much reduced in the $\mathrm{KO}$ animals. Thus, injecting Wnt3a-expressing AAV induced canonical signaling around the injection site and a $\beta$-catenin-dependent increase in the density of YFP + OPCs.

Injecting $\mathrm{AAV}-\mathrm{Wnt} 3 \mathrm{a}$ increased the density of NG2 + OPCs in the vicinity of the injection site (Fig. 9A-C) whereas after injection of either AAV-GFP or AAVWnt5a, the density of OPCs did not change significantly. After injection of AAV-Wnt3a, OPCs at the injection site were tightly clustered and had enlarged cell bodies and increased immunoreactivity to the NG2 CSPG (Fig. 9B). Injection of AAV-Wnt5a also altered the morphology of OPCs; they had fewer but longer processes. This may reflect activated planar polarity pathways. The Wnt3amediated increase in cell density was due, at least in part, to increased cell division as the incorporation of BrdU into OPCs after a pulse label was increased fourfold in the Wnt3a-injected animals compared with AAV-eGFP-injected animals (Fig. 9C). The BrdU-positive cells were clustered around the injection site (data not shown). These results show that the initiation of canon- 
A
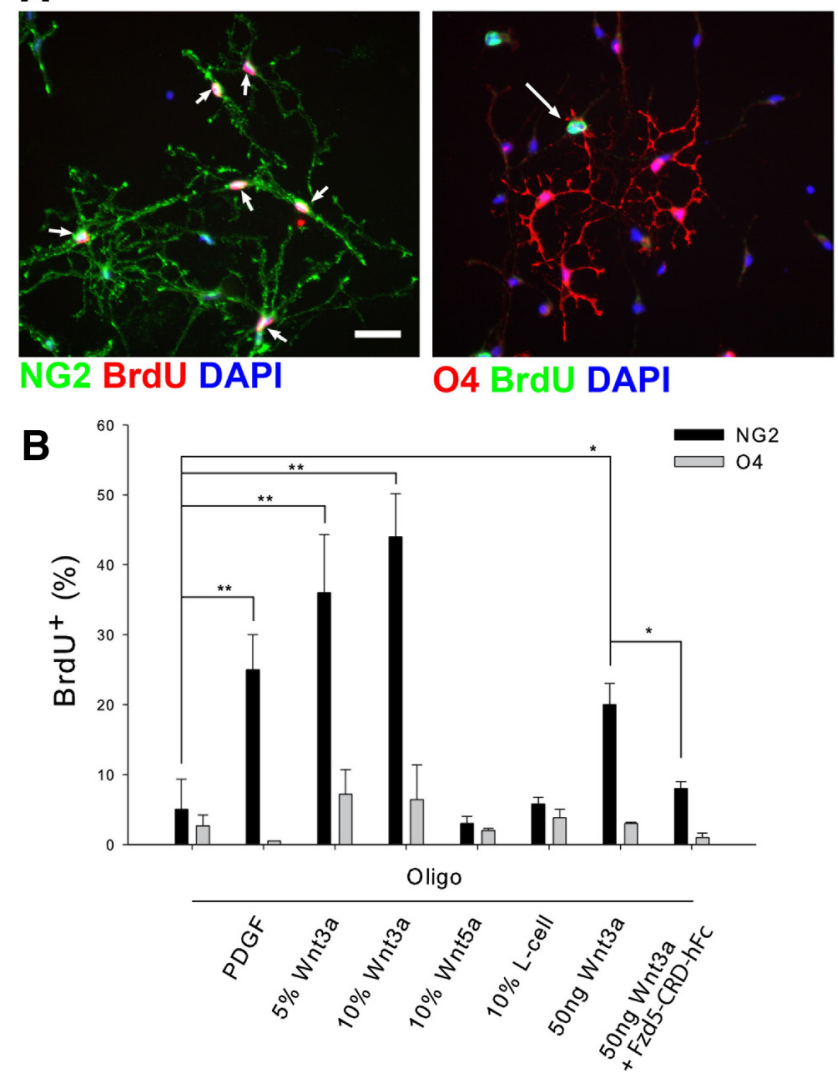

Figure 11. Wnt3a is mitogenic for OPCs. $A, N G 2+O P C s$ but not $04+$ pre-oligodendrocytes incorporate BrdU after exposure to canonical Wnt3a. Arrows point to double-labeled cells. Scale bar, $50 \mu \mathrm{m}$. B, Quantitation of BrdU incorporation for OPCs grown in oligodendrocyte media containing the indicated additives. Addition of an IgG-Frizzled-CRD fusion protein inhibits the effect of Wnt $3 \mathrm{a} ;{ }^{*} p=0.02,{ }^{* *} p<0.001$, where not indicated, results were not significant, $n \geq 4$ in all cases. A minimum of 150 cells were counted for each condition in each experiment.

ical Wnt signaling in adult OPCs stimulates their proliferation and accumulation similar to what occurs after acute SCI.

We also examined the effects of Wnt overexpression on microglia and astrocytes. Consistent with previous studies showing that microglia respond to exogenous Wnts (Halleskog et al., 2011; Kilander et al., 2011), injection of AVV-Wnt3a increased the density of Iba1 + microglia fivefold; injection of AAV-Wnt5a also increased microglial cell density, albeit to a lesser degree (Fig. $10 A, B)$. There were no differences in the percentage of Iba1+ cells incorporating BrdU after a $2 \mathrm{~h}$ pulse between the control and Wnt3a-injected or Wnt5a-injected animals (data not shown). Neither Wnt3A nor Wnt5A increased the density of GFAPpositive astrocytes (Fig. $10 A, B$ ), but both Wnts lead to significant increases in GFAP expression (Fig. 10C). The effects of Wnt5a on GFAP expression were more modest than that of Wnt3a. These results demonstrate that the increased expression of Wnt3a provokes an injury-like response in glial cells. While this suggests a key role of canonical Wnt signaling in regulating the glial responses to SCI, we cannot rule out a contribution of noncanonical signaling.

Last, to confirm that canonical Wnt signaling is mitogenic to OPCs, we grew neonatal rat OPCs in culture, treated the cells with media conditioned by L-cells secreting either Wnt3a or Wnt5a, and measured BrdU incorporation into the cells. As shown in Figure 11, exposure to Wnt3a-conditioned media but not Wnt5a-conditioned media stimulated BrdU incorporation into
NG2+ OPCs. Purified soluble Wnt3a was also an effective mitogen and its effects were blocked by soluble Frizzled5-CRD-hFc, which blocks the binding of Wnts to their LRP receptors (Ishikawa et al., 2001; Yamamoto et al., 2006; DeAlmeida et al., 2007). Neither Wnt3a nor Wnt5a stimulated BrdU incorporation into $\mathrm{O} 4+$ pre-oligodendrocytes.

\section{Discussion}

Glial cells react to injury of the brain or spinal cord by forming a complex scar tissue at the injury site. This scar is both beneficial and detrimental to wound healing and damage repair (Rolls et al., 2009). In the early stages of wound healing, astrocytes form a barrier that keeps invading cells, mostly macrophages and leukocytes, out of the undamaged areas (Faulkner et al., 2004; Hermann et al., 2008). They are also important factors in the re-establishment of the blood-brain barrier. At later stages, however, astrocytes, together with degenerating oligodendrocytes, OPCs, and meningeal cells, create a biochemical environment that is nonpermissive for axon regeneration (Fitch and Silver, 2008). Although this suggests that preventing scar formation might promote axonal regeneration (Fawcett et al., 2012), ablating reactive astrocytes or suppressing their reaction to injury leads paradoxically to more extensive damage and reduced repair, most likely because of an increased early inflammatory response (Faulkner et al., 2004; Hermann et al., 2008). Here we have shown that preventing canonical Wnt signaling in OPCs not only suppresses their reactions to the injury but also reduces the reactions of microglia and astrocytes. Together these reduced glial reactions create an environment that is supportive rather than repressive to axonal regeneration and repair.

Wnts are secreted morphogens known mostly for their role as regulators of pattern formation and cell fate during early development (Moon et al., 1997). They also have complex effects on developing oligodendrocyte precursor cells. Canonical Wnt signaling delays the differentiation of OPCs into myelinating oligodendrocytes (Shimizu et al., 2005; Fancy et al., 2009; Feigenson et al., 2009), but it also upregulates the expression of proteolipid protein in mouse oligodendrocytes (Tawk et al., 2011). In the uninjured adult CNS, Wnts regulate adult neurogenesis in the dentate gyrus (Lie et al., 2005) and multiple aspects of synaptic transmission (Inestrosa and Arenas, 2010). Canonical Wnt signaling is also mitogenic to those adult neural stem cells that specifically generate oligodendrocytes (Ortega et al., 2013). Although there is ongoing $\beta$-catenin-dependent Wnt signaling in adult OPCs (White et al., 2010; Fig. 2), reducing this signaling in OPCs by deleting $\beta$-catenin did not alter either the density or appearance of OPCs at least over a $25 \mathrm{~d}$ time course. Thus $\beta$-catenin-dependent signaling is not necessary for the normal slow proliferation of adult OPCs. The binding of platelet-derived growth factor, a major mitogen for OPCs, to its $\alpha$-receptor in developing OPCs activates both Wnt- $\beta$-catenin-dependent and PI3K-mTor-dependent signaling pathways, both of which can drive cell proliferation (Hill et al., 2013). Thus, the Wnt pathway may be dispensable for basal proliferation. In contrast, $\beta$-catenin signaling is necessary for the injury-induced rapid proliferation of OPCs and increasing Wnt3a expression in the uninjured spinal cord is sufficient to initiate proliferation and a reactive response in OPCs. Thus increases in the expression of Wnts and their receptors after SCI (Liu et al., 2008b; Miyashita et al., 2009; Fernández-Martos et al., 2011; Gonzalez et al., 2012) are likely responsible, at least in part, for the rapid proliferation and mobilization of OPCs after injury. 
Eliminating $\beta$-catenin-dependent signaling in OPCs had striking and unexpected consequences for the reactions to injury of other glial cells. Both microglia/macrophage accumulation and astrocyte hypertrophy were significantly reduced. This suggests that the OPC reactive response regulates the responses of microglia/macrophages. We can only speculate as to the mechanisms underlying these cell nonautonomous effects on microglia. First, CSPGs can directly activate microglia in vitro (Rolls et al., 2008). Reactive OPCs and astrocytes are major sources of secreted and cell-associated CSPGs after injury (Levine, 1994; Asher et al., 2000) and the expression of CSPGs is reduced in the $\beta$-catenin $\mathrm{KO}$ animals. Consistent with the notion that reducing CSPGs can reduce microglial reactions to injury is the finding that there is reduced inflammation after lysolecithin-induced demyelination in the spinal cords of NG2-null mice (Kucharova et al., 2011). Second, canonical Wnt signaling activates microglia and increases the expression of pro-inflammatory cytokines in vitro (Halleskog et al., 2011). As demonstrated here (Fig. 10), Wnt3a causes a robust activation and accumulation of microglia in vivo. Oligodendrocyte lineage cells express high levels of Wnt3 mRNA (Ortega et al., 2013) and Wnt mRNA is detected in NG2positive cells after SCI (Liu et al., 2008a). This suggests that by reducing the number of reactive OPCs, we may have reduced Wnt tone and availability to other cells, including microglia, in the injured area. The reduced number of axin $2+$ cells throughout the injured spinal cord (Fig. 2) is consistent with this idea. Third, because the same percentage of microglia incorporated $\mathrm{BrdU}$ in both the control and $\mathrm{KO}$ animals, $\beta$-catenin deletion in OPCs is likely to affect the mobilization and migration of microglia and macrophages into the glial scar rather than their proliferation. Reactive OPCs secrete MMP9, which can open the blood-brain barrier (Seo et al., 2013), and they are a potential source of chemokines and chemoattractants for inflammatory cells. Reducing any of these functions would attenuate the inflammatory response. Regardless of the exact mechanism, it is clear that there are complex interactions between activated OPCs and activated microglia/macrophages (Wu et al., 2002). Cytokines produced by activated microglia and platelets induce reactive changes in OPCs (Rhodes et al., 2006) and these reactive changes, together with an increase in OPC number, are necessary for the accumulation and activation of microglia. Deleting $\beta$-catenin-dependent signaling in OPCs appears to disrupt these complex interactions leading to both a reduced accumulation of OPCs and a reduced inflammatory response to SCI.

Since astrocyte hypertrophy may be induced by activated microglia (Emmetsberger and Tsirka, 2012), the attenuation of microglia activation in the $\mathrm{KO}$ animals could lead to the reduced astrocyte hypertrophy and reduced expression of GFAP. In the injured normal spinal cord, the barrier formed by reactive astrocytes in the early stages of wound healing confines microglia/ macrophages to the injured areas (Faulkner et al., 2004). In the $\beta$-catenin $\mathrm{KO}$ animals, although the barrier between the injured spinal cord and non-neural tissue and cells is reduced and there are fewer hypertrophic astrocytes (Fig. 5), inflammation is also reduced. Thus manipulating the OPC reaction to injury has dramatic effects on the overall development and characteristics of the glial scar. The activation of OPCs is a common feature of several different types of CNS injury (Levine et al., 2001). Perturbing this activation by reducing canonical Wnt signaling has revealed an essential role for these cells in orchestrating the responses of several different cell types to injury.

One technical question that arises is how can a relatively small number of induced cells have such a striking effect on the terrain of the damaged spinal cord. Recombination efficiency at any specific locus is influenced by many factors including the local concentration of tamoxifen, the kinetics of nuclear import of $\mathrm{cre}$, the distance between LoxP sites, and local chromatin structure (Vooijs et al., 2001). Although only $\sim 12-15 \%$ of the NG2positive OPCs in the uninjured spinal cord express YFP after tamoxifen treatment, this is likely to be an underestimation of the true number of cells that have either undergone recombination at the $\beta$-catenin locus or failed to activate Wnt-dependent intracellular signaling pathways. First, overall axin2 immunoreactivity, a direct readout of Wnt signaling, is greatly reduced in the KO spinal cords compared with control animals (Fig. 2). Second, we estimate that $\sim 63 \%$ of the NG2 + cells at $5 \mathrm{dpl}$ in control animals express axin 2 whereas only $40 \%$ of the NG2+ cells in the KO animals are axin $2+$. Considering that injured control animals have three times more NG2+ cells in the penumbral region at 5 $\mathrm{dpl}$ than do the $\beta$-catenin-KO animals, we calculate that there are $\sim 4$-fold fewer Wnt responding OPCs per unit volume surrounding the injury site in the $\mathrm{KO}$ animals relative to control animals. This reduction is sufficient to reduce the extent of glial scarring. Third, when we compared the percentage of YFP-positive cells labeled with BrdU after a pulse at 2 and $5 \mathrm{~d}$ post injury to the percentage of all the NG2-positive cells (both YFP positive and YFP negative) that had incorporated BrdU, the numbers were identical. Thus the total NG2-positive cell population behaved identically to a smaller YFP-positive population. These considerations suggest that recombination at the Rosa26 locus is less efficient than recombination at the $\beta$-catenin locus and we had, in fact, deleted $\beta$-catenin from large numbers of OPCs. It is important to note that by reducing overall Wnt tone (see above), we may have also reduced the injury responses of those OPCs that did not undergo recombination at the $\beta$-catenin locus.

The glial scar is considered both a physical and chemical barrier to successful axon regrowth (Fitch and Silver, 2008). Numerous factors contribute to this barrier function including the secretion of CSPGs by astrocytes and reactive OPCs (Asher et al., 2000; Tan et al., 2006), inhibitory molecules contained within myelin debris (Lee and Zheng, 2012), repulsive axon guidance molecules secreted by invading meningeal cells (De Winter et al., 2002), and contact repulsion mediated by invading macrophages (Horn et al., 2008). By eliminating $\beta$-catenin-dependent signaling in OPCs, we created an environment that is permissive to axon regeneration even in the absence of manipulating the growth state of the retinal ganglion cells. This is consistent with the notion that adult neurons are not intrinsically incapable of regeneration, rather the environment of the damaged CNS prevents regeneration (David and Aguayo, 1981). Targeting Wnt signaling either alone or combined with other approaches (Lu et al., 2012) may be a basis for designing new therapies for encouraging axonal repair and regeneration.

\section{References}

Asher RA, Morgenstern DA, Fidler PS, Adcock KH, Oohira A, Braistead JE, Levine JM, Margolis RU, Rogers JH, Fawcett JW (2000) Neurocan is upregulated in injured brain and in cytokine-treated astrocytes. J Neurosci 20:2427-2438. Medline

Benowitz LI, Yin Y (2010) Optic nerve regeneration. Arch Ophthalmol 128: 1059-1064. CrossRef Medline

Brault V, Moore R, Kutsch S, Ishibashi M, Rowitch DH, McMahon AP, Sommer L, Boussadia O, Kemler R (2001) Inactivation of the betacatenin gene by Wnt1-Cre-mediated deletion results in dramatic brain malformation and failure of craniofacial development. Development 128: 1253-1264. Medline

Bush TG, Puvanachandra N, Horner CH, Polito A, Ostenfeld T, Svendsen CN, Mucke L, Johnson MH, Sofroniew MV (1999) Leukocyte infiltra- 
tion, neuronal degeneration, and neurite outgrowth after ablation of scarforming, reactive astrocytes in adult transgenic mice. Neuron 23:297-308. CrossRef Medline

Cadigan KM, Liu YI (2006) Wnt signaling: complexity at the surface. J Cell Sci 119:395-402. CrossRef Medline

Dahl D, Bignami A (1974) Heterogeneity of the glial fibrillary acidic protein in gliosed human brains. J Neurol Sci 23:551-563. CrossRef Medline

David S, Aguayo AJ (1981) Axonal elongation into peripheral nervous system "bridges" after central nervous system injury in adult rats. Science 214:931-933. CrossRef Medline

DeAlmeida VI, Miao L, Ernst JA, Koeppen H, Polakis P, Rubinfeld B (2007) The soluble wnt receptor Frizzled8CRD-hFc inhibits the growth of teratocarcinomas in vivo. Cancer Res 67:5371-5379. CrossRef Medline

De Winter F, Oudega M, Lankhorst AJ, Hamers FP, Blits B, Ruitenberg MJ, Pasterkamp RJ, Gispen WH, Verhaagen J (2002) Injury-induced class 3 semaphorin expression in the rat spinal cord. Exp Neurol 175:61-75. CrossRef Medline

Donnelly EM, Madigan NN, Rooney GE, Knight A, Chen B, Ball B, Kinnavane L, Garcia Y, Dockery P, Fraher J, Strappe PM, Windebank AJ, O'Brien T, McMahon SS (2012) Lentiviral vector delivery of short hairpin RNA to NG2 and neurotrophin-3 promotes locomotor recovery in injured rat spinal cord. Cytotherapy 14:1235-1244. CrossRef Medline

Emmetsberger J, Tsirka SE (2012) Microglial inhibitory factor (MIF/TKP) mitigates secondary damage following spinal cord injury. Neurobiol Dis 47:295-309. CrossRef Medline

Ertürk A, Mauch CP, Hellal F, Förstner F, Keck T, Becker K, Jährling N, Steffens H, Richter M, Hübener M, Kramer E, Kirchhoff F, Dodt HU, Bradke F (2012) Three-dimensional imaging of the unsectioned adult spinal cord to assess axon regeneration and glial responses after injury. Nat Med 18:166-171. CrossRef Medline

Fancy SP, Baranzini SE, Zhao C, Yuk DI, Irvine KA, Kaing S, Sanai N, Franklin RJ, Rowitch DH (2009) Dysregulation of the Wnt pathway inhibits timely myelination and remyelination in the mammalian CNS. Genes Dev 23:1571-1585. CrossRef Medline

Faulkner JR, Herrmann JE, Woo MJ, Tansey KE, Doan NB, Sofroniew MV (2004) Reactive astrocytes protect tissue and preserve function after spinal cord injury. J Neurosci 24:2143-2155. CrossRef Medline

Fawcett JW, Schwab ME, Montani L, Brazda N, Müller HW (2012) Defeating inhibition of regeneration by scar and myelin components. Handb Clin Neurol 109:503-522. CrossRef Medline

Feigenson K, Reid M, See J, Crenshaw EB 3rd, Grinspan JB (2009) Wnt signaling is sufficient to perturb oligodendrocyte maturation. Mol Cell Neurosci 42:255-265. CrossRef Medline

Fernández-Martos CM, González-Fernández C, González P, Maqueda A, Arenas E, Rodríguez FJ (2011) Differential expression of Wnts after spinal cord contusion injury in adult rats. PLoS One 6:e27000. CrossRef Medline

Fitch MT, Silver J (2008) CNS injury, glial scars, and inflammation: inhibitory extracellular matrices and regeneration failure. Exp Neurol 209:294301. CrossRef Medline

Giulian D, Chen J, Ingeman JE, George JK, Noponen M (1989) The role of mononuclear phagocytes in wound healing after traumatic injury to adult mammalian brain. J Neurosci 9:4416-4429. Medline

Gonzalez P, Fernandez-Martos CM, Gonzalez-Fernandez C, Arenas E, Rodriguez FJ (2012) Spatio-temporal expression pattern of frizzled receptors after contusive spinal cord injury in adult rats. PLoS One 7:e50793. CrossRef Medline

Gundersen HJ (1986) Stereology of arbitrary particles. A review of unbiased number and size estimators and the presentation of some new ones, in memory of William R. Thompson. J Microsc 143:3-45. CrossRef Medline

Gundersen HJ, Jensen EB, Kiêu K, Nielsen J (1999) The efficiency of systematic sampling in stereology-reconsidered. J Microsc 193:199-211. CrossRef Medline

Halleskog C, Mulder J, Dahlström J, Mackie K, Hortobágyi T, Tanila H, Kumar Puli L, Färber K, Harkany T, Schulte G (2011) WNT signaling in activated microglia is proinflammatory. Glia 59:119-131. CrossRef Medline

Hermann PM, Nicol JJ, Bulloch AG, Wildering WC (2008) RGDdependent mechanisms in the endoneurial phagocyte response and axonal regeneration in the nervous system of the snail Lymnaea stagnalis. J Exp Biol 211:491-501. CrossRef Medline

Hill RA, Patel KD, Medved J, Reiss AM, Nishiyama A (2013) NG2 cells in white matter but not gray matter proliferate in response to PDGF. J Neurosci 33:14558-14566. CrossRef Medline

Horn KP, Busch SA, Hawthorne AL, van Rooijen N, Silver J (2008) Another barrier to regeneration in the CNS: activated macrophages induce extensive retraction of dystrophic axons through direct physical interactions. J Neurosci 28:9330-9341. CrossRef Medline

Inestrosa NC, Arenas E (2010) Emerging roles of Wnts in the adult nervous system. Nat Rev Neurosci 11:77-86. CrossRef Medline

Ishikawa T, Tamai Y, Zorn AM, Yoshida H, Seldin MF, Nishikawa S, Taketo MM (2001) Mouse Wnt receptor gene Fzd5 is essential for yolk sac and placental angiogenesis. Development 128:25-33. Medline

Jho EH, Zhang T, Domon C, Joo CK, Freund JN, Costantini F (2002) Wnt/ beta-catenin/Tcf signaling induces the transcription of Axin2, a negative regulator of the signaling pathway. Mol Cell Biol 22:1172-1183. CrossRef Medline

Kilander MB, Halleskog C, Schulte G (2011) Recombinant WNTs differentially activate beta-catenin-dependent and -independent signalling in mouse microglia-like cells. Acta Physiol 203:363-372. CrossRef Medline

Kimelman D, Xu W (2006) Beta-catenin destruction complex: insights and questions from a structural perspective. Oncogene 25:7482-7491. CrossRef Medline

Kucharova K, Chang Y, Boor A, Yong VW, Stallcup WB (2011) Reduced inflammation accompanies diminished myelin damage and repair in the NG2 null mouse spinal cord. J Neuroinflammation 8:158. CrossRef Medline

Kurimoto T, Yin Y, Omura K, Gilbert HY, Kim D, Cen LP, Moko L, Kügler S, Benowitz LI (2010) Long-distance axon regeneration in the mature optic nerve: contributions of oncomodulin, cAMP, and pten gene deletion. J Neurosci 30:15654-15663. CrossRef Medline

Lee JK, Zheng B (2012) Role of myelin-associated inhibitors in axonal repair after spinal cord injury. Exp Neurol 235:33-42. CrossRef Medline

Leon S, Yin Y, Nguyen J, Irwin N, Benowitz LI (2000) Lens injury stimulates axon regeneration in the mature rat optic nerve. J Neurosci 20:46154626. Medline

Levine JM (1994) Increased expression of the NG2 chondroitin-sulfate proteoglycan after brain injury. J Neurosci 14:4716-4730. Medline

Levine JM, Stincone F, Lee YS (1993) Development and differentiation of glial precursor cells in the rat cerebellum. Glia 7:307-321. CrossRef Medline

Levine JM, Reynolds R, Fawcett JW (2001) The oligodendrocyte precursor cell in health and disease. Trends Neurosci 24:39-47. CrossRef Medline

Lie DC, Colamarino SA, Song HJ, Désiré L, Mira H, Consiglio A, Lein ES, Jessberger S, Lansford H, Dearie AR, Gage FH (2005) Wnt signalling regulates adult hippocampal neurogenesis. Nature 437:1370-1375. CrossRef Medline

Liu C, Wang Y, Smallwood PM, Nathans J (2008a) An essential role for Frizzled5 in neuronal survival in the parafascicular nucleus of the thalamus. J Neurosci 28:5641-5653. CrossRef Medline

Liu Y, Wang X, Lu CC, Kerman R, Steward O, Xu XM, Zou Y (2008b) Repulsive Wnt signaling inhibits axon regeneration after CNS injury. J Neurosci 28:8376-8382. CrossRef Medline

Lu W, Lin C, King TD, Chen H, Reynolds RC, Li Y (2012) Silibinin inhibits Wnt/beta-catenin signaling by suppressing Wnt co-receptor LRP6 expression in human prostate and breast cancer cells. Cell Signal 24:22912296. CrossRef Medline

Lustig B, Jerchow B, Sachs M, Weiler S, Pietsch T, Karsten U, van de Wetering M, Clevers H, Schlag PM, Birchmeier W, Behrens J (2002) Negative feedback loop of Wnt signaling through upregulation of conductin/axin2 in colorectal and liver tumors. Mol Cell Biol 22:1184-1193. CrossRef Medline

Lytle JM, Wrathall JR (2007) Glial cell loss, proliferation and replacement in the contused murine spinal cord. Eur J Neurosci 25:1711-1724. CrossRef Medline

Lytle JM, Chittajallu R, Wrathall JR, Gallo V (2009) NG2 cell response in the CNP-EGFP mouse after contusive spinal cord injury. Glia 57:270-285. CrossRef Medline

McCarthy KD, de Vellis J (1980) Preparation of separate astroglial and oligodendroglial cell cultures from rat cerebral tissue. J Cell Biol 85:890-902. CrossRef Medline

McTigue DM, Wei P, Stokes BT (2001) Proliferation of NG2-positive cells and altered oligodendrocyte numbers in the contused rat spinal cord. J Neurosci 21:3392-3400. Medline 
Meyer RL, Miotke J (1990) Rapid initiation of neurite outgrowth onto laminin from explants of adult mouse retina induced by optic nerve crush. Exp Neurol 107:214-221. CrossRef Medline

Meyer RL, Miotke JA, Benowitz LI (1994) Injury induced expression of growth-associated protein- 43 in adult mouse retinal ganglion cells in vitro. Neuroscience 63:591-602. CrossRef Medline

Miyashita T, Koda M, Kitajo K, Yamazaki M, Takahashi K, Kikuchi A, Yamashita T (2009) Wnt-Ryk signaling mediates axon growth inhibition and limits functional recovery after spinal cord injury. J Neurotrauma 26:955-964. CrossRef Medline

Moon RT, Brown JD, Torres M (1997) WNTs modulate cell fate and behavior during vertebrate development. Trends Genet 13:157-162. CrossRef Medline

Morgan JM, Navabi H, Schmid KW, Jasani B (1994) Possible role of tissuebound calcium ions in citrate-mediated high-temperature antigen retrieval. J Pathol 174:301-307. CrossRef Medline

Morgan JM, Navabi H, Jasani B (1997) Role of calcium chelation in hightemperature antigen retrieval at different $\mathrm{pH}$ values. J Pathol 182:233237. CrossRef Medline

Nishiyama A, Komitova M, Suzuki R, Zhu X (2009) Polydendrocytes (NG2 cells): multifunctional cells with lineage plasticity. Nat Rev Neurosci 10: 9-22. CrossRef Medline

Ortega F, Gascón S, Masserdotti G, Deshpande A, Simon C, Fischer J, Dimou L, Chichung Lie D, Schroeder T, Berninger B (2013) Oligodendrogliogenic and neurogenic adult subependymal zone neural stem cells constitute distinct lineages and exhibit differential responsiveness to Wnt signalling. Nat Cell Biol 15:602-613. CrossRef Medline

Paukert M, Bergles DE (2006) Synaptic communication between neurons and NG2+ cells. Curr Opin Neurobiol 16:515-521. CrossRef Medline

Petrosyan HA, Hunanyan AS, Alessi V, Schnell L, Levine J, Arvanian VL (2013) Neutralization of inhibitory molecule NG2 improves synaptic transmission, retrograde transport, and locomotor function after spinal cord injury in adult rats. J Neurosci 33:4032-4043. CrossRef Medline

Rhodes KE, Raivich G, Fawcett JW (2006) The injury response of oligodendrocyte precursor cells is induced by platelets, macrophages and inflammation-associated cytokines. Neuroscience 140:87-100. CrossRef Medline

Rivers LE, Young KM, Rizzi M, Jamen F, Psachoulia K, Wade A, Kessaris N, Richardson WD (2008) PDGFRA/NG2 glia generate myelinating oligodendrocytes and piriform projection neurons in adult mice. Nat Neurosci 11:1392-1401. CrossRef Medline

Rolls A, Shechter R, London A, Segev Y, Jacob-Hirsch J, Amariglio N, Rechavi G, Schwartz M (2008) Two faces of chondroitin sulfate proteoglycan in spinal cord repair: a role in microglia/macrophage activation. PLoS Med 5:e171. CrossRef Medline

Rolls A, Shechter R, Schwartz M (2009) The bright side of the glial scar in CNS repair. Nat Rev Neurosci 10:235-241. CrossRef Medline

Seo JH, Miyamoto N, Hayakawa K, Pham LD, Maki T, Ayata C, Kim KW, Lo EH, Arai K (2013) Oligodendrocyte precursors induce early bloodbrain barrier opening after white matter injury. J Clin Invest 123:782-786. CrossRef Medline

Shimizu T, Kagawa T, Wada T, Muroyama Y, Takada S, Ikenaka K (2005) Wnt signaling controls the timing of oligodendrocyte development in the spinal cord. Dev Biol 282:397-410. CrossRef Medline
Silver J, Miller JH (2004) Regeneration beyond the glial scar. Nat Rev Neurosci 5:146-156. CrossRef Medline

Simon C, Götz M, Dimou L (2011) Progenitors in the adult cerebral cortex: cell cycle properties and regulation by physiological stimuli and injury. Glia 59:869-881. CrossRef Medline

Sommer JM, Smith PH, Parthasarathy S, Isaacs J, Vijay S, Kieran J, Powell SK, McClelland A, Wright JF (2003) Quantification of adeno-associated virus particles and empty capsids by optical density measurement. Mol Ther 7:122-128. CrossRef Medline

Tan AM, Colletti M, Rorai AT, Skene JH, Levine JM (2006) Antibodies against the NG2 proteoglycan promote the regeneration of sensory axons within the dorsal columns of the spinal cord. J Neurosci 26:4729-4739. CrossRef Medline

Tang X, Falls DL, Li X, Lane T, Luskin MB (2007) Antigen-retrieval procedure for bromodeoxyuridine immunolabeling with concurrent labeling of nuclear DNA and antigens damaged by HCl pretreatment. J Neurosci 27:5837-5844. CrossRef Medline

Tawk M, Makoukji J, Belle M, Fonte C, Trousson A, Hawkins T, Li H, Ghandour S, Schumacher M, Massaad C (2011) Wnt/beta-catenin signaling is an essential and direct driver of myelin gene expression and myelinogenesis. J Neurosci 31:3729-3742. CrossRef Medline

Valenta T, Hausmann G, Basler K (2012) The many faces and functions of beta-catenin. EMBO J 31:2714-2736. CrossRef Medline

Vooijs M, Jonkers J, Berns A (2001) A highly efficient ligand-regulated Cre recombinase mouse line shows that LoxP recombination is position dependent. EMBO Rep 2:292-297. CrossRef Medline

White RE, McTigue DM, Jakeman LB (2010) Regional heterogeneity in astrocyte responses following contusive spinal cord injury in mice. J Comp Neurol 518:1370-1390. CrossRef Medline

Wu DC, Jackson-Lewis V, Vila M, Tieu K, Teismann P, Vadseth C, Choi DK, Ischiropoulos H, Przedborski S (2002) Blockade of microglial activation is neuroprotective in the 1-methyl-4-phenyl-1,2,3,6-tetrahydropyridine mouse model of Parkinson disease. J Neurosci 22:1763-1771. Medline

Yamamoto H, Komekado H, Kikuchi A (2006) Caveolin is necessary for Wnt-3a-dependent internalization of LRP6 and accumulation of betacatenin. Dev Cell 11:213-223. CrossRef Medline

Yan D, Wiesmann M, Rohan M, Chan V, Jefferson AB, Guo L, Sakamoto D, Caothien RH, Fuller JH, Reinhard C, Garcia PD, Randazzo FM, Escobedo J, Fantl WJ, Williams LT (2001) Elevated expression of axin2 and hnkd mRNA provides evidence that Wnt/beta-catenin signaling is activated in human colon tumors. Proc Natl Acad Sci U S A 98:14973-14978. CrossRef Medline

Yang Z, Watanabe M, Nishiyama A (2005) Optimization of oligodendrocyte progenitor cell culture method for enhanced survival. J Neurosci Methods 149:50-56. CrossRef Medline

Young KM, Psachoulia K, Tripathi RB, Dunn SJ, Cossell L, Attwell D, Tohyama K, Richardson WD (2013) Oligodendrocyte dynamics in the healthy adult CNS: evidence for myelin remodeling. Neuron 77:873-885. CrossRef Medline

Zawadzka M, Rivers LE, Fancy SP, Zhao C, Tripathi R, Jamen F, Young K, Goncharevich A, Pohl H, Rizzi M, Rowitch DH, Kessaris N, Suter U, Richardson WD, Franklin RJ (2010) CNS-resident glial progenitor/ stem cells produce Schwann cells as well as oligodendrocytes during repair of CNS demyelination. Cell Stem Cell 6:578-590. CrossRef Medline 